\title{
New genera and species of Australian Restionaceae (Poales)
}

\author{
Barbara G. Briggs and L.A.S. Johnson ${ }^{\dagger}$
}

\begin{abstract}
Briggs, Barbara G. and Johnson, L.A.S. (Royal Botanic Gardens, Mrs Macquaries Road, Sydney, NSW 2000, Australia) 1998. New genera and species of Australian Restionaceae (Poales). Telopea 7(4): 345-373. Sixteen new genera and five new species of Australian Restionaceae are described and combinations made for a further eleven species. Newly described genera are Catacolea, Kulinia, Guringalia, Acion, Saropsis, Chordifex, Eurychorda, Platychorda, Tremulina, Melanostachya, Taraxis, Tyrbastes, Cytogonidium, Stenotalis, Dapsilanthus, Apodasmia. Newly described type species are: Catacolea enodis, Kulinia eludens, Chordifex stenandrus, Taraxis grossa, Tyrbastes glaucescens. New combinations are made for the type species of the remaining genera: Guringalia dimorpha, Acion monocephalum, Saropsis fastigiata, Eurychorda complanata, Platychorda applanata, Tremulina tremula, Melanostachya ustulata, Cytogonidium leptocarpoides, Stenotalis ramosissima, Dapsilanthus elatior, Apodasmia brownii. Lectotypes are selected for several species. Brief comment is included on culm anatomy, flavonoids, seed ornamentation and DNA findings, in addition to exomorphological features. Keys are provided to distinguish the new genera from other members of the Desmocladus, Loxocarya and Leptocarpus groups. All the new genera occur in Australia but Apodasmia also includes species in New Zealand and Chile while Dapsilanthus is represented also in New Guinea, Aru Islands and Southeast Asia.
\end{abstract}

\section{Introduction}

The last comprehensive systematic account of Australian Restionaceae was by Bentham (1878), building especially on the notable work of Brown (1810) and Mueller (1872-4). Subsequently 12 relevant new genera have been described, but two of these, Desmocladus Nees and Baloskion Raf., were never adopted by botanists in Australia and one, Sporadanthus F. Muell., was considered to be a New Zealand endemic. Over recent decades we have developed a revised classification, including 16 new genera (described here) and 51 new species. Publications are in preparation to describe the further new species of many of these genera.

The morphology of Restionaceae may be partly responsible for the inadequate nature of early classifications of the Australian members. The leaves are reduced to sheathing scales and the wind-pollinated flowers mainly differ in the extent of reduction of floral parts. The dearth of exomorphological characters, however, conceals a diversity of anatomical characters, as shown by the extensive studies of Gilg (1890) and Cutler $(1969,1972)$ who drew attention to many discrepancies between the existing classification and anatomical findings. Structures mentioned here, such as peg-cells, pillar cells and protective cells, are described by Cutler (1969). Anatomical studies have been extended to the rhizome and roots by Pate \& Delfs (in press) and Meney, Pate \& Hickman (in press). Palynology (Chanda 1966, Linder 1984, Linder \& Ferguson 1985) and flavonoids (Harborne 1979, Williams et al. 1997 \& in press) also show diversity largely concordant with the major distinctions between Australian and African groups and assist in characterising some genera. The early classifications also reflect the inadequacies of the available collections since many species and several genera are rare and of restricted distribution, so that they were not represented in early collections.

† Deceased 1 August 1997 
Our classification, or partially developed aspects of it, have been used in a number of contexts in advance of validation of the new names (Rye 1987; Pate, Meney \& Dixon 1991; Pate, Raisins, Thumfort, McCheseney \& Meney 1995; Linder 1992; Meney, Pate \& Dixon 1996; Meney, Dixon \& Pate 1997; Williams et al. 1997 \& in press; Meney \& Pate in press; Meney, Pate \& Hickman in press; Briggs \& Johnson in press).

The present paper arises from the need to validate names in advance of the treatment of Restionaceae in The Families and Genera of Flowering Plants, edited by K. Kubitzki, (Linder, Briggs \& Johnson in press ). We describe the newly distinguished genera and make combinations for, or describe, their type species. The genera are treated in a systematic sequence, as in Linder et al. (op. cit.) and keys are provided to distinguish the new genera from other members of the Desmocladus, Loxocarya and Leptocarpus groups. The species referred to the new genera, where not monotypic, are enumerated in Briggs \& Johnson (in press). Further information and illustrations of all Australian taxa are given by Meney \& Pate (in press) and Meney, Pate \& Hickman (in press). The new taxa will be placed in context in the treatment of the family in the Flora of Australia (Briggs, Johnson, Porter \& Krauss in prep.) and, so far as practical in advance of that treatment, in revisions of individual genera. All types cited have been examined. Precise locations are not given for collections of very rare species.

\section{Descriptions of taxa, new combinations and distinguishing features}

\section{Desmocladus group (Briggs \& Johnson in press)}

The new genera Catacolea and Kulinia are placed in the Desmocladus group, so a partial key to genera of this group is provided. DNA sequence data (Briggs, Marchant, Gilmore \& Porter unpublished results) show that the members of this group sampled, apart from Empodisma which has been regarded as its least specialised member, form a robust association.

\section{Partial key to Desmocladus group}

(i.e. Western Australian genera with single style and chlorenchyma not interrupted by pillar cells or sclerenchyma girders). (Names of new genera in bold.)

1 Culms simple, culm sheaths lacking or 1-3

$1^{*}$ Culms branching or simple, culm sheaths $>3$

Desmocladus, Harperia, Lepidobolus

2 Culms densely pubescent; male spikelets 2-7-flowered Kulinia

2* Culms glabrous; male spikelets many-flowered 3

3 Culms strongly flattened, male spikelets on slender pendulous or patent stalks Catacolea

$3^{*}$ Culms not flattened, male spikelets terminal or axillary on culms

Onychosepalum

Catacolea B.G. Briggs \& L.A.S. Johnson, gen. nov.

Plantae glabrae; culmi valde compressi; vaginae culmorum deficientes vel raro unicae; spiculae masculinae multiflorae saepe pendulae, pedunculis tenuibus; spiculae femineae pauciflorae.

Type species: C. enodis B.G. Briggs \& L.A.S. Johnson 
Dioecious. Caespitose, glabrous, with glossy dark brown to straw-coloured basal sheaths. Culms simple, strongly flattened, straight or curved, glabrous, mostly of a single internode, rarely with a persistent appressed sheath mid-culm. Inflorescence subtended by a small scarious bract. Male inflorescence terminal, of 1-several manyflowered spikelets on short slender pendulous or patent peduncles. Female inflorescence of 1 terminal spikelet with 1-several flowers and several sterile lower glumes. Flowers: tepals (4)5(6), membranous. Male flowers: stamens 3, anthers exserted. Female flowers: ovary 1-locular, style 1. Fruit a nut; shed with persistent pedicel, perianth, and stylar beak. Seed smooth, with an irregular pattern of subangular cells.

Culm flattened and lacking a central cavity; chlorenchyma not interrupted, of 1 layer of elongated peg-cells; pillar and protective cells absent, but inward-projecting epidermal cells partially lining the substomatal cavity; epidermal cells with radial walls not or scarcely sinuous but thickened on outer wall and outer part of radial walls; radially elongated epidermal cells forming mounds on the culm surface; with vascular bundles in central ground tissue. Catacolea is distinct in its flavonoids from allied genera (Williams et al. in press); containing quercetin, kaempferol, isorhamnetin, and gossypetin 7-methyl ether, also differing from all other members of the Desmocladus group of genera except Coleocarya in lacking flavones.

The name is from the Greek kata-, down, below, basal, and coleus, a sheath, referring to the prominent basal sheaths, whereas sheaths are lacking on the culm.

Within the Desmocladus group the many-flowered spikelets on slender peduncles and the broad compressed culms of Catacolea are distinctive. The culm nodes few or lacking further distinguish Catacolea from all genera except Onychosepalum and Kulinia. Catacolea is glabrous unlike the densely pubescent Kulinia and differs from the latter in the presence of tepals in female flowers.

A genus of one rare species in the south-west of Western Australia, in a seasonally dry region.

Catacolea enodis B.G. Briggs E L.A.S. Johnson, sp. nov.

Culmi 10-30 cm longi, 1.2-2 mm lati; spiculae masculinae floribus c. 70; spiculae femineae floribus 1-3, tepalis plerumque 5 .

Type: Western Australia: E of Brand Hwy on Green Head-Coorow road, Alexander Morrison National Park, (c. 30S, 115³0'E), B.G. Briggs 7740 E L.A.S. Johnson, 30 Sep 1984 \& (holo: NSW; iso K, MEL, MO, PERTH).

Forming small dense clumps of many culms, with short ascending rhizomes. Culms erect or recurved, 10-30 cm long, 1.2-2.0 mm wide, tuberculate, yellowish green. Sheaths: almost all basal, closely overlapping, persistent, glossy dark-brown to strawcoloured, outer sheaths c. $1 \mathrm{~cm}$ long, but inner sheaths to c. $3 \mathrm{~cm}$ long, with a short subulate lamina up to c. $3 \mathrm{~mm}$ long; cauline sheaths when present $1-1.8 \mathrm{~cm}$ long, loosely appressed, pale-brown, striate, with a short subulate lamina $2-3 \mathrm{~mm}$ long. Inflorescence subtended by a green to straw-coloured bract, $0.6-1.0 \mathrm{~cm}$ long, with a subulate tip 1.5-2.5 mm long. Male inflorescence of 1-3 ovoid spikelets, 7-12 mm long, 6-9 mm wide; lower 2 glumes sterile; upper c. 70 glumes fertile, 5-6 mm long, lanceolate, acuminate, smooth, scarious, golden-brown, glabrous, without a mucro or awn. Female spikelets narrow-ovoid, 13-15 mm long, 2.0-3.8 mm wide, 1-3-flowered; glumes 3-5, rigid, broad-lanceolate, mucronate, 6-7 mm long; mucro erect, $2.5-3.2 \mathrm{~mm}$ long, glossy, dark-brown, glabrous. Male flowers: outer tepals aristate, $3.7-4.5 \mathrm{~mm}$ long; inner tepals lanceolate, $2.2-3.3 \mathrm{~mm}$ long; filaments $3.0-4.5 \mathrm{~mm}$ long; anthers 1.6-2.1 mm long. Female flowers: outer tepals keeled, 5.5-7.0 mm long; inner tepals 


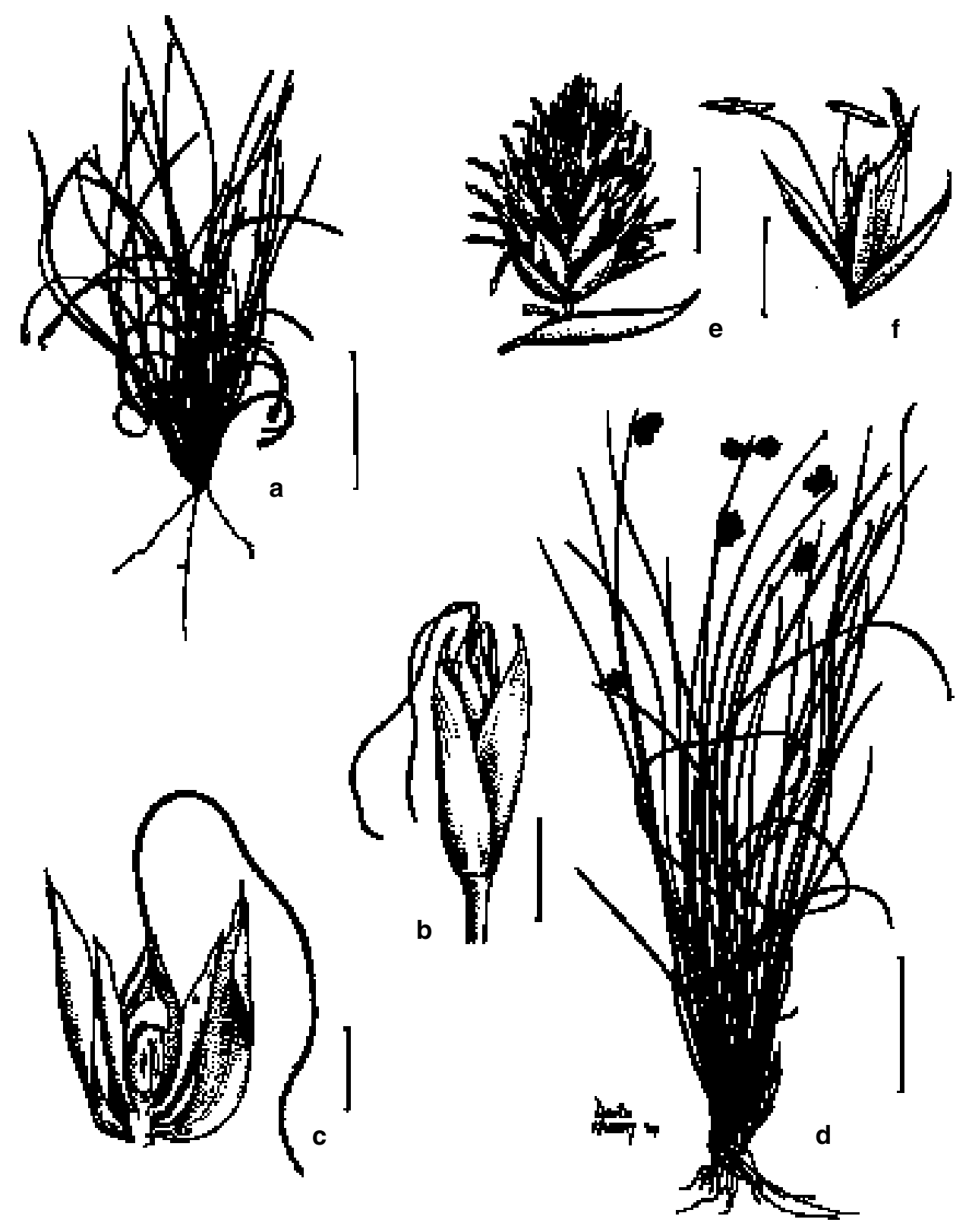

Fig. 1. Catacolea enodis. a-c, female: a, habit. $\mathbf{b}$, spikelet. $\mathbf{c}$, flower (holotype). $\mathbf{d}-\mathbf{f}$, male: $\mathbf{d}$, habit. e, spikelet. f, flower (Briggs 7739). Scale bars: $a, d=7 \mathrm{~cm} ; \mathrm{b}, \mathrm{c}, \mathrm{e}, \mathrm{f}=2 \mathrm{~mm}$. 
lanceolate, 5.0-5.5 mm long. Nut 3.5-4 mm long, c. $2 \mathrm{~mm}$ wide. Seed smooth, ellipsoid, chestnut-brown, glossy, c. $1.8 \mathrm{~mm}$ long (Fig. 1).

Occurs in the Alexander Morrison National Park area, c. 200 km N of Perth, W.A., in tall heath on deep white sand over laterite.

The epithet is from the Latin $e^{-}$, without, and nodus, a node, referring to the culms which mostly consist of a single internode.

Conservation status: Rare, vulnerable, some populations not endangered but poorly known (Meney, Pate, Dixon, Briggs \& Johnson in press), Western Australian CALM Conservation Code P3, proposed ROTAP Code 2RC-.

Specimens examined: Western Australia: Irwin: E of Brand Highway on Green Head-Coorow road, Alexander Morrison National Park, Briggs $7728 \mathcal{E}$ Johnson, 30 Sep 1984 ơ (NSW), 7729 q (NSW, K, MEL, MO, PERTH), $7729 a$ (NSW, AD, CANB, RSA), 7730 (NSW, BRI, DNA, NBG, NY, PERTH), 7739 ơ (NSW, AD, BRI, CANB, K, MEL, MO, NBG, PERTH), 7741 오 (NSW, AD, K, MEL, MO); c. 140 km NNW of Gingin, Aplin \& Coveny 3177 o, ,, 2 Sep 1970 (NSW); W of Brand Hwy on Bibby Road, Briggs 9383 \& Pate, 6 Oct 1995 ơ (NSW), Briggs 8578 E Johnson, Linder, Pate $\mathcal{E}$ Meney, 6 Sep 1990 ? (NSW, BOL, CANB, K, KPBG).

Kulinia B.G. Briggs \& L.A.S. Johnson, gen. nov.

$\mathrm{Ab}$ Onychosepalum combinatione characterum sequentium distinguitur: plantae dense albipubescentes, pilis basi longis; spiculae masculinae pauciflorae solitariaeque; spiculae femineae aliquot per culmum uniflorae, tepalis nullis.

Type species: Kulinia eludens B.G. Briggs \& L.A.S. Johnson

Dioecious. Caespitose, the base densely villous with long hairs. Culms simple, terete, pubescent, with 1-3 persistent sheaths. Male inflorescence a solitary terminal spikelet, 2-7-flowered. Female inflorescence of 2 or 3 spikelets, each 1-flowered and terminal or axillary, with several sterile glumes; outer glumes with a dark rigid mucro, inner glumes membranous. Male flowers: tepals 2-5, membranous, stamens 3, anthers exserted. Female flowers lacking tepals, ovary unilocular, style 1. Fruit a thin-walled small nut.

Culms with chlorenchyma not interrupted, of 1 layer of elongated peg-cells, pillar and protective cells absent; inward-projecting epidermal cells partially lining the substomatal cavity; epidermal cells thickened on outer wall and outer part of radial walls but radial walls not sinuous; culm with vascular bundles in central ground tissue, central cavity absent but central cells thin-walled; with stalked, branched multicellular hairs. Kulinia has a unique flavonoid pattern among Australian Restionaceae based on chrysoeriol and flavone C-glycosides (Williams et al. in press), although the latter compounds are also found in some species of several related genera.

The name refers to Kulin, a small town east of Narrogin in Western Australia, near which the one known species occurs.

A genus of one rare species in the south of Western Australia in a seasonally dry region.

Kulinia eludens B.G. Briggs E L.A.S. Johnson, sp. nov.

Culmi usque ad $15 \mathrm{~cm}$ longi simplices, teretes vel teretiusculi; vaginae culmorum 1-3; inflorescentiae femineae spiculis 2 vel 3.

Type: Western Australia: Kulin Nature Reserve, ESE of Kulin (c. $\left.32^{\circ} 40^{\prime S}, 118^{\circ} 20^{\prime} \mathrm{E}\right)$, B.G. Briggs 8531 E L.A.S. Johnson, 1 Nov 1988 o (holo NSW; iso AD, B, BRI, K, MEL, MO, NBG, PERTH, RSA).

In small clumps to $15 \mathrm{~cm}$ diam., or in circular patches to $30 \mathrm{~cm}$ diam., sometimes dying in the centre and forming spreading rings to $50 \mathrm{~cm}$ diam.; with a conspicuous tuft of 
long dense white hairs at the base of the culms. Culms erect or spreading, terete or almost so, often flexuose and tangled above the first internode, pubescent with dense short white hairs, the culms appearing grey-green, to $15 \mathrm{~cm}$ long, $0.5-1.0 \mathrm{~mm}$ diam.; internodes 2-4, to $10 \mathrm{~cm}$ long, smooth. Sheaths loosely appressed, $0.5-1.5 \mathrm{~cm}$ long, narrow-ovate, \pm acute, red- to pale-brown, sparsely pilose; lamina erect, c. $1 \mathrm{~mm}$ long. Male spikelets: narrow-elliptic, c. 4.0-5.0 mm long; subtending bract longer than spikelet; mucro 1.0-1.5 mm long; glumes 2-7, ovate-lanceolate, acute, 3.0-3.5 mm long, pale-brown with a membranous margin, glabrous or sparsely pubescent with short pilose hairs; mucro c. $0.8 \mathrm{~mm}$ long. Female spikelets: narrow-ellipsoid, $5.0-7.0 \mathrm{~mm}$ long; subtending bract longer and almost completely enclosing spikelet; mucro c. $1.0 \mathrm{~mm}$ long; glumes 6 or 7, narrow-ovate, acute, 3.1-4.2 $\mathrm{mm}$ long, brown with membranous margins, abaxial surface partially pilose; mucro to $2.2 \mathrm{~mm}$ long; the 2 uppermost glumes reduced, c. $2.7 \mathrm{~mm}$ long with a filiform base. Male flowers: lowest flower in spikelet with 5 tepals, upper flowers with 2 tepals, tepals obtuse; outer tepals narrow-lanceolate, $2.5-3.3 \mathrm{~mm}$ long; inner tepals linear, often twisted, 2.0-2.6 mm long; anthers 1.2-1.4 mm long. Nut: pale brown, c. $2.8 \mathrm{~mm}$ long including the short pedicel and beak at base of the style (Fig. 2).

The epithet refers to the species eluding us and not being found on our first attempts to locate the site of its original discovery.
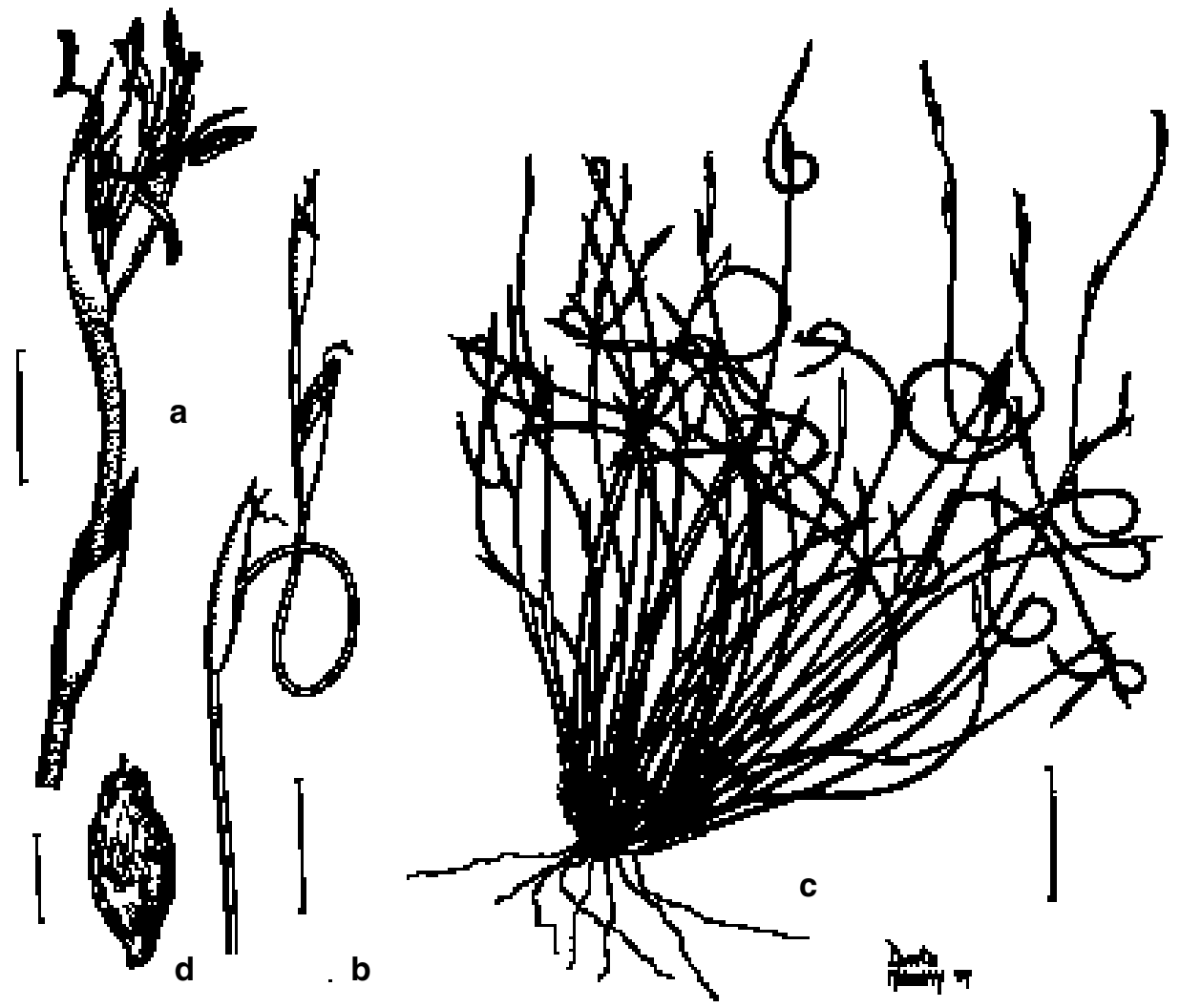

Fig. 2. Kulinia eludens. a, male inflorescence (Briggs 8530). b, c, female: b, inflorescence. c, habit (holotype). $\mathbf{d}$, fruit (Briggs 9352). Scale bars: $\mathrm{a}=3 \mathrm{~mm} ; \mathrm{b}=6 \mathrm{~mm} ; \mathrm{c}=2.5 \mathrm{~cm} ; \mathrm{d}=1.2 \mathrm{~mm}$. 
Currently known only from Kulin Nature Reserve (Hopkins Reserve) and c. 27 km S of Hyden. Grows on deep pale-yellow sand in openings in open shrubland. Regenerates from seed after fire.

Conservation status: Rare, endangered (Meney, Pate, Dixon, Briggs \& Johnson in press), ROTAP Code 2KCit (Briggs \& Leigh 1996), as 'Loxocarya eludens'.

Specimens examined: Western Australia: Roe: c. $25 \mathrm{~km} \mathrm{~S}$ of Hyden, W of Holt Rock (W of Lake King-Hyden road), Briggs 8522 \& Johnson, 1 Nov 1988 \& (NSW); [Hopkins Reserve] SE of Kulin, R. Hnatiuk 770315, 13 July 1977 \& (PERTH, NSW), R. Hnatiuk 850001, 3 Nov 1985 \& (PERTH, NSW), Briggs 8530 E L.A.S. Johnson, 1 Nov 1988 ơ (CANB, K, MO, PERTH), Briggs 9351 \& Pate, 4 Oct 1995 ơ (NSW, NBG, PERTH), 9352 \& (NSW, MO, PERTH).

\section{Loxocarya group (Briggs \& Johnson in press)}

Almost all the described species of this group were included in an extremely wide and unnatural concept of Restio. Morphological features (when carefully investigated), anatomical, palynological and phytochemical data are all consistent in supporting the restriction of Restio to species of the African region, and showing that Restio, thus restricted, is more closely allied to other African genera than to the extra-African taxa formerly referred to Restio (Cutler 1969, Johnson \& Briggs 1981, Linder \& Ferguson 1985, Linder et al. in press, Briggs \& Johnson in press, and unpublished data of Linder, Barker, Briggs and Johnson).

DNA data suggest that the Loxocarya group may be paraphyletic with respect to some or all of the Winifredia, Desmocladus and Leptocarpus groups. For the present time, however, while further investigations continue and since the present DNA data do not give conclusive evidence, the groupings recognised by Briggs \& Johnson (in press) are maintained as informal categories. The DNA data also suggest that the conspicuous anatomical feature of pillar cells interrupting the chlorenchyma may be less reliable than we had originally thought and the circumscription of the Loxocarya group reflects the possibility that pillar cells have originally been more widespread and are now lost from genera including Guringalia, Baloskion, Acion, Saropsis, Tremulina, Dielsia, Tyrbastes and others.

\section{Key to genera of the Loxocarya group}

1 Female flowers subterranean except for style and stigmatic branches which emerge above ground level; rhizome and culm bases sheathed by glossy scales; rhizomes long and slender Alexgeorgea

$1^{*}$ Female flowers not subterranean; rhizome and culm bases sheathed by dull or glossy scales; rhizomes long or short or plant caespitose

2 Chlorenchyma continuous, not interrupted by pillar cells, girders or enlarged epidermal cells; culm usually not striate

2* Chlorenchyma interrupted by pillar cells, girders or enlarged epidermal cells; culm usually longitudinally striate

3 Female flower attached to glume; capsule falling with glume and perianth attached; female flowers with 4 tepals; seeds smooth..... Baloskion

3* Female flower not attached to glume; capsule not falling at seed dispersal; female flowers with 6 tepals; seeds striate with longitudinal lines of convex cells 4

4 Female spikelets with $>5$ flowers; culms simple or sparingly branched; chlorenchyma 2-3 cells thick 
$4^{*}$ Female spikelets 1-flowered; culms little- or much-branched; chlorenchyma 1 cell thick

5 Sheaths lax; culms repeatedly branched Saropsis

$5^{*}$ Sheaths appressed; culms simple below the inflorescence 5

6 Female spikelet structure not conspicuous (flowers singly in axil of a herbaceous bract or the glumes of the spikelet scarcely overlapping, not forming a compact spikelet), culms repeatedly branched 7

$6^{*}$ Female spikelet structure conspicuous (multi-glumed spikelets with overlapping glumes), culms simple or branched

7 Rhizomatous; culms stout, 10-15 mm diam at base; female flowers singly in axils of bracts, tepals 2 or 3 , reduced to minute deltoid scales c. $0.7 \mathrm{~mm}$ long; commonly with large galls that resemble much-enlarged spikelets Taraxis

$7^{*}$ Caespitose, culms not stout, $1-1.5 \mathrm{~mm}$ diam. at base; female flowers $1-3$ in spikelets with herbaceous glumes scarcely overlapping, tepals 6, 3-4 mm long; not commonly galled Tyrbastes

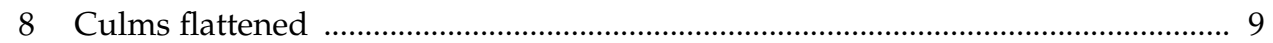

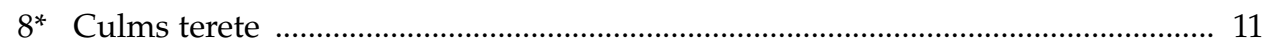

9 Male flowers with 2 stamens; anthers exserted; female flowers with 4 tepals Eurychorda

9* Male flowers with 3 stamens; anthers not exserted; female flowers with 6 tepals 10

10 Ovary 3-locular; style branches 3; seed surface of subangular or slightly lobed cells in an irregular pattern. Platychorda

10* Ovary 2-locular; style branches 2; seed surface of rhombic cells in longitudinal lines Tremulina

11 Female spikelets 1-flowered; culms dimorphic with fertile culms erect but sterile culms more branched and flexuose Loxocarya

$11^{*}$ Female spikelets several- or many-flowered; culms not dimorphic, simple or branched

12 Male and female spikelets more than $10 \mathrm{~mm}$ long ........................................... 13

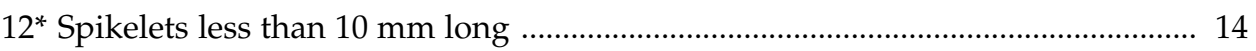

13 Spikelets ovoid, more than $3 \mathrm{~mm}$ diam.; glumes rigid and black

Melanostachya

13* Spikelets cylindrical, less than $3 \mathrm{~mm}$ diam.; glumes scarious-membranous Dielsia

14 Chlorenchyma interrupted by pillar cells; male spikelets erect and anthers exserted (in all except in C. microcodon) Chordifex

$14^{*}$ Chlorenchyma interrupted by enlarged epidermal cells; male spikelets pendulous and anthers not exserted 
Guringalia B.G. Briggs \& L.A.S. Johnson, gen. nov.

A Baloskion combinatione characterum sequentium distinguitur: culmi ramosi; spiculae femineae uniflorae, floribus tepalis 6, a glumis liberis; capsula rigidula, seminibus longitudinaliter striatis, striis e cellulis convexis serialibus constatis.

Type species: Guringalia dimorpha (R. Br.) B.G. Briggs \& L.A.S. Johnson

Dioecious. Rhizomatous, the base pubescent. Culms repeatedly branched, erect or sinuous, glabrous; sheaths persistent, lax. Inflorescence of spikelets, terminal or axillary on culm and on short branches at several upper nodes. Male spikelets with 3-8 flowers and 7 or 8 sterile lower glumes. Female spikelets with 1 flower and 7-10 sterile lower glumes. Flowers: tepals 6. Male flowers: outer tepals keeled, keel villous; inner tepals flat; stamens 3, anthers exserted. Female flowers: outer tepals sparsely pubescent, ovary 2-locular but often 1 loculus aborted, style branches 2 . Fruit a firmwalled capsule. Seeds striate with longitudinal lines of convex cells. $2 n=14$ (Briggs 1963, as Restio dimorphus) (Fig. 3d-3f).

Culm with chlorenchyma of 1 layer of elongated cells, not interrupted, pillar and protective cells absent, central cavity present. Guringalia and Saropsis differ from Baloskion in containing the flavonoids hypolaetin and sometimes flavonoid sulphates (Williams et al. in press).

The name refers to the Guringai (or Kuring-gai), a name applied to the tribal group of indigenous people of much of the region in the Central Coast of New South Wales where the only species occurs.

Guringalia, Acion and Saropsis resemble Baloskion in having culms with uninterrupted chlorenchyma. The three new genera, however, share the following features which distinguish them from Baloskion: female flowers free from the glume, tepals 6, capsule with a firm pericarp which is not late-dehiscent, and striate seeds. By contrast, Baloskion has tepals 4, capsule with a thin and papery pericarp, seed dispersal by a late-dehiscent capsule attached to the glume, and the seeds are smooth. Acion differs from Guringalia in its unbranched or sparsely branched culms and multi-flowered female spikelets. Saropsis differs from Guringalia in its appressed culm sheaths and culms unbranched below the inflorescence but with highly branched inflorescences. In addition, Guringalia has chlorenchyma of 2-3 layers of cells, whereas Acion and Saropsis have a single layer of elongated cells; Baloskion shows 1-3 layers of cells in the chlorenchyma, with different conditions in different species.

A genus of one species in the Sydney region of Eastern Australia, in well-drained or seasonally moist sites.

Guringalia dimorpha (R. Br.) B.G. Briggs E L.A.S. Johnson, comb. nov.

Basionym: Restio dimorphus R. Brown, Prodr.: 246 (1810).

Type citation: (J.) v.v.

Type: New South Wales: Port Jackson, R. Brown No. 13, 1802-5 $q$ (lecto, here selected, BM). Residual syntype: Port Jackson, R. Brown No. 13, 1802-5 ô (BM; isosyn E, MEL 15106).

Acion B.G. Briggs \& L.A.S. Johnson, gen. nov.

A Guringalia combinatione characterum sequentium distinguitur: culmi simplices vel pauciramosi; spiculae femineae multiflorae; chlorenchyma e stratis cellularum 2 vel 3 formatum.

Type species: Acion monocephalum (R. Br.) B.G. Briggs \& L.A.S. Johnson 


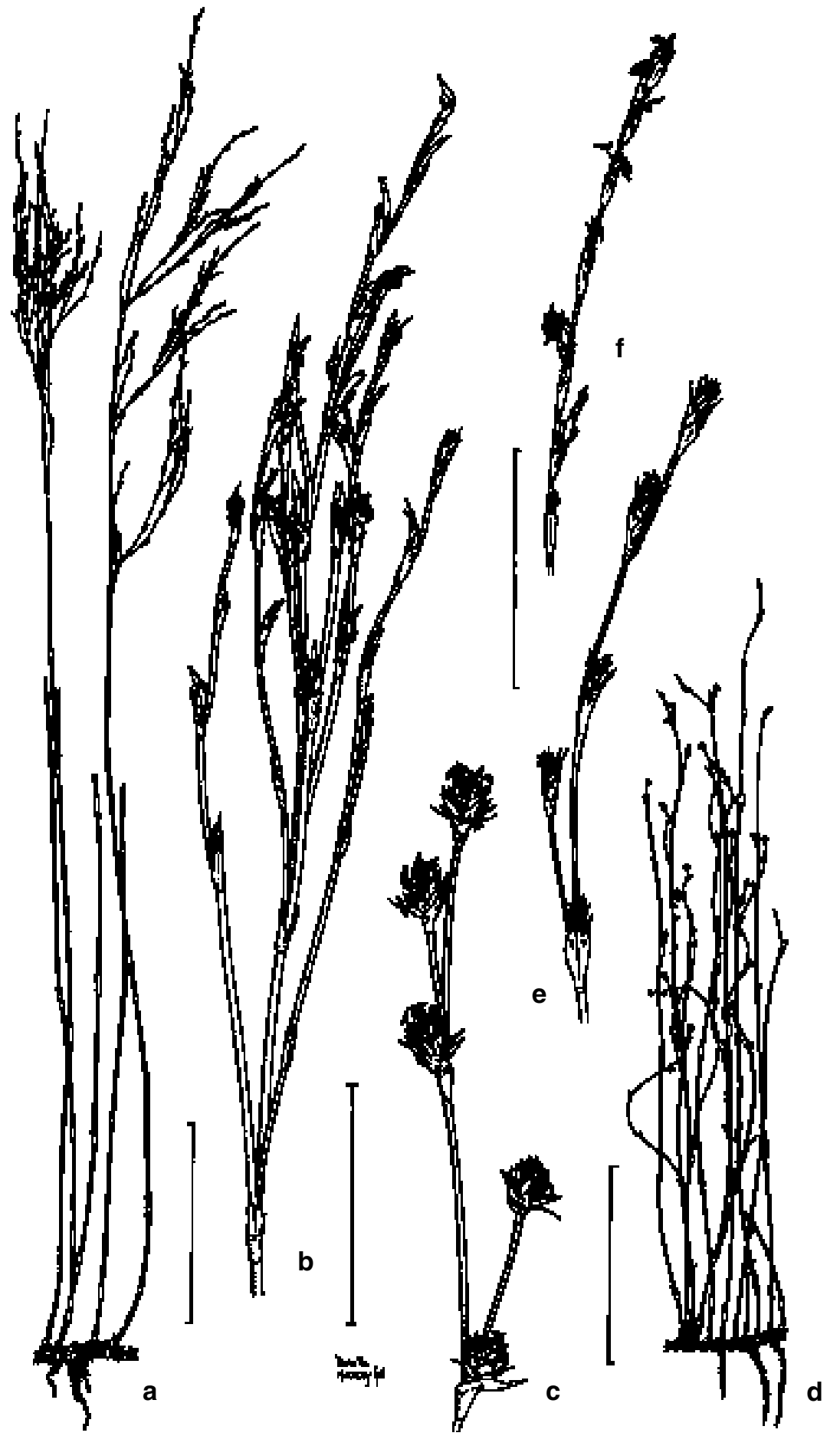

Fig. 3. a-c, Saropsis fastigiata. a, habit (Hind 3217a). b, female inflorescence (Hartley 14290). c, male inflorescence (Constable, 16 Oct 1957). d-f, Guringalia dimorpha. d, habit (Constable 7306). e, female inflorescence (Johnson, 6 Nov 1948). $\mathbf{f}$, male inflorescence (Benson 2358). Scale bars: $\mathrm{a}, \mathrm{d}=10 \mathrm{~cm}$; $\mathrm{b}, \mathrm{c}, \mathrm{e}, \mathrm{f}=2 \mathrm{~cm}$. 
Dioecious. Rhizomatous, the rhizome pubescent. Culms unbranched or sparingly branched, erect, glabrous, sheaths persistent, lax. Inflorescence of spikelets terminal on culm or axillary at several upper nodes. Spikelets multiflowered (with 6-17 flowers and 5-20 sterile lower glumes). Flowers: tepals 6. Male flowers: outer tepals keeled, keel villous, inner tepals flat; stamens 3, anthers fully or partially exserted. Female flowers: tepals glabrous, ovary loculi and style branches 2 . Fruit a firm-walled capsule. Seeds striate with longitudinal lines of convex cells. $2 n=32$ (Briggs 1963, as Restio monocephalus).

Culm with chlorenchyma of 2-3 layers of elongated cells, not interrupted, pillar and protective cells absent, central cavity present. The flavonoids of Acion resemble those of some Baloskion species (Williams et al. in press).

The name is from the Greek $a-$, without, and kion, a pillar or column, referring to the continuous chlorenchyma of the culms, which is not interrupted by pillar cells.

Differences from related genera are given under Guringalia.

A genus of two species in Tasmania, in well-drained or seasonally wet sites on sand or peat.

Acion monocephalum (R. Br.) B.G. Briggs E L.A.S. Johnson, comb. nov.

Basionym: Restio monocephalus R. Brown, Prodr.: 245 (1810).

Type citation: (D.) v.v.

Type: Tasmania: In ericetis inter Baie du nord ouest fl. Derwent, R. Brown, Apr 1804 우 (holo BM; probable iso K).

Saropsis B.G. Briggs \& L.A.S. Johnson, gen. nov.

A Guringalia combinatione characterum sequentium distinguitur: culmi infra inflorescentias simplices sed inflorescentiae ramosissimae; vaginae culmorum appressae; spiculae femineae uniflorae vel pauciflorae.

Type species Saropsis fastigiata (R. Br.) B.G. Briggs \& L.A.S. Johnson

Dioecious. Rhizomatous, the rhizome short and pubescent. Culms unbranched below the inflorescence but with numerous elongated inflorescence branches, erect, glabrous, sheaths persistent, appressed. Inflorescence of narrow spikelets, terminal or axillary at many upper nodes of inflorescence branches. Male spikelets: c. 7-flowered, all glumes fertile. Female spikelets: 1-flowered, with several sterile lower glumes. Flowers: tepals 6. Male flowers: tepals glabrous, 2 outer tepals keeled; stamens 3, anthers exserted. Female flowers: tepals usually ciliate; ovary loculi and style branches 2 . Fruit a firmwalled capsule. Seeds striate with longitudinal lines of convex cells. $2 n=14$ (Briggs 1963, as Restio fastigiatus) (Fig. 3a-3c).

Culm with chlorenchyma of 1 layer of elongated cells, interrupted by greatly enlarged epidermal cells which meet and sometimes interrupt the parenchyma sheath opposite short sclerenchyma girders over the outer vascular bundles; pillar and protective cells absent; central cavity present. Saropsis and Guringalia differ from Baloskion in containing the flavonoids hypolaetin and sometimes flavonoid sulphates (Williams et al. in press).

The name is from the Greek saron, a broom and opsis, appearance, likeness, referring (as does the specific epithet of the only species) to the clustered and much-branched inflorescence branches.

Differences from related genera are given under Guringalia. 
A genus of one species, in eastern Australia in central coastal New South Wales and also south-east Queensland; in seasonally moist sandy soils.

Saropsis fastigiata (R. Br.) B.G. Briggs E L.A.S. Johnson, comb. nov.

Basionym: Restio fastigiatus R. Brown, Prodr.: 246 (1810).

Type citation: (J.) v.v.

Type: New South Wales: Port Jackson, R. Brown, 1802-5 ơ (holo BM; iso E, MEL 14868).

Chordifex B.G. Briggs E L.A.S. Johnson, gen. nov.

Rhizomata pubescentes; spiculae erectae (spiculae masculinae raro pendulae), pauciflorae vel multiflorae; tepala 5 or 6 , pari extimo carinato; stamina 3 , antheris exsertis (raro inclusis); loculi stylique 2 (raro 1); fructus capsulares seminibus longitudinaliter striatis, striis e cellulis convexis serialibus constatis; chlorenchyma e stratis cellularum 1-3 formatum, cellulis columnaribus interruptum.

Type species: Chordifex stenandrus B.G. Briggs \& L.A.S. Johnson

Dioecious. Caespitose or rhizomatous, the base pubescent. Culms simple or much branched, erect or flexuose, terete, striate, glabrous or the lowest internode pubescent, with persistent appressed or lax sheaths; the lowest internode often elongated and slender. Male and female inflorescences similar, the flowers in erect spikelets (except the males pendulous in ' $C$. microcodon'), terminal or several clustered in upper axils or many in a slender much-branched inflorescence; spikelets with several or many flowers and several or many sterile lower glumes. Male flowers: tepals 5 or 6 , glabrous or adaxially pubescent, 2 outer tepals keeled; stamens 3, anthers exserted (except in 'C. microcodon'); pistillode present or absent. Female flowers: tepals mostly similar to males, staminodes 0-3, loculi and style branches 2 (except reduced to 1 in 'C. leucoblepharus' and usually in 'C. sphacelatus'). Fruit a firm-walled capsule. Seeds striate with longitudinal lines of convex cells (sometimes imprinted with a further striate or irregular pattern) or the lines exaggerated into sharp ridges of radially elongated cells.

Culm with chlorenchyma of 1-3 layers of short peg-cells, interrupted by pillar cells opposite outer vascular bundles, protective cells absent, central cavity mostly present. The flavonoids of Chordifex were found to be heterogeneous (Williams et al. in press); groupings based on flavonoid patterns are not congruent with those based on morphological studies.

The name is from the Latin chorda, a rope or twine, and -fex, a maker; Chordifex and Restio both having the same meaning of 'rope-maker'.

On morphological grounds this appears to be a relatively coherent genus, despite some diversity, but DNA data suggest that it may not be monophyletic. For this reason, the type species is chosen from among those included in the DNA analyses, although this has led to the choice of a rare and, until now, undescribed species. Publication of other new combinations and the description of other undescribed species of Chordifex are in preparation.

Differences from some related genera are given under Platychorda.

A genus of seventeen species of the south of Western Australia; mostly in mesic regions on soils of low fertility.

Chordifex stenandrus B.G. Briggs E L.A.S. Johnson, sp. nov.

Planta rhizomatosa; culmi simplices, $30-80 \mathrm{~cm}$ longi; vaginae culmorum laxae, $1-2.5 \mathrm{~cm}$ longae, obtusae vel truncatae, ciliatae; inflorescentiae tenues spiculis numerosis; flores masculini tepalis anguste linearibus; capsulae 3.5-4 mm longae. 
Type: Western Australia: SE of Mt Lesueur, N of Jurien-Coomallo Rd on track E of Mt Lesueur, B. Briggs 7473 E L. Johnson, 29 Sep 1984 \& (holo NSW; iso AD, CANB, K, MEL, NBG, PERTH, PRE, RSA).

Rhizome horizontal, up to c. $10 \mathrm{~cm}$ long, 2.5-4.5 mm diam., densely pubescent, partly covered by brown to pale-brown, scarious cataphylls. Culms spaced up to c. $1 \mathrm{~cm}$ apart, erect, straight, terete, simple, $30-80 \mathrm{~cm}$ long, 1-2 mm diam., green, mostly glabrous but the lowest internodes shortly woolly pubescent; internodes several, c. 3-10 cm long. Sheaths appressed at the base, distally lax and open, narrow-obovate, 1.0-2.5 cm long, striate, pale to red-brown; apex obtuse to truncate, shortly ciliate; lamina narrow, erect, 1-2 mm long with a narrow, membranous margin. Inflorescence narrow, erect, 4-20 cm long; subtending bracts similar to culm sheaths but shorter. Male spikelets narrow-ellipsoid, 7-9 $\mathrm{mm}$ long, c. $2 \mathrm{~mm}$ wide; sterile lower glumes 5-12, fertile upper glumes 5-7; glumes narrow-lanceolate, light- to dark-brown, glabrous, acuminate, $6.0-7.5 \mathrm{~mm}$ long. Female spikelets narrow-obovoid to campanulate, 9-12 mm long, 2-4 mm wide; sterile lower glumes 4-8, fertile upper glumes 2-3, narrow-elliptical, light- to dark-brown, glabrous, mucronate, 7-9 mm long; mucro dark-brown, $0.5-1.0 \mathrm{~cm}$ long. Male flowers: tepals 5 or 6, narrow linear, membranous, brown; outer tepals sparsely pubescent, 5-6 $\mathrm{mm}$ long; inner tepals flat, glabrous, 4.0-4.5 mm long; filaments 5-6 mm long; anthers c. $2.4 \mathrm{~mm}$ long; pistillode minute. Female flowers: tepals 5, narrow-lanceolate; outer tepals 6-7 mm long; inner tepals 4-5 mm long; staminodes 3; ovary 2-locular, but sometimes only 1 locule developing. Capsule c. 3.5-4 mm long, smooth, brown. Seeds oblong, c. $1.9 \mathrm{~mm}$ long; the surface white, colliculate (Fig. 4).

Occurs in the Mt Lesueur district, inland from Jurien. Grows in intermittently moist watercourses in heath on yellow sand with some lateritic gravel washed from nearby hills.

Conservation status: Rare, vulnerable (Meney, Pate, Dixon, Briggs \& Johnson in press), ROTAP Code 2KC- (Briggs \& Leigh 1996), as 'Restio stenandra'.

Specimens examined: Western Australia: Irwin: W of Brand Hwy on Green Head Rd from 'Half Way' Roadhouse, c. $30 \mathrm{~km}$ (direct) S of Eneabba, Briggs 8601, Johnson, Meney, Pate \& Linder, 7 Sep 1990 o (NSW, BOL), 8602 오, (NSW, BOL); N of Mt Benia and ENE of Mt Lesueur, NE of Jurien, Griffin 2300, 21 Sep 1979 ô (PERTH); hill NE of Mt Lesueur, NE of Jurien, Griffin 2534, 17 Nov 1979 $\delta$ (PERTH), 2535 $\uparrow$ (PERTH); SE of Mt Lesueur, N of Jurien-Coomallo Rd on track E of Mt Lesueur, Briggs 7474 \& Johnson, 29 Sep 1984 ㅇ (NSW, K, MO, PERTH), 7475 o (NSW, CANB, PERTH, PRE, RSA), 7476 (galled, NSW, NBG, PERTH), 7477 ơ (NSW, NBG, CANB); Brand Hwy, N of Jurien turnoff, Meney 3892, 16 Sep 1992 (voucher for DNA sample, grown from tissue culture from wild source) (NSW); Brand Hwy, N of Jurien turn-off (near Tootbardi Farm), c. $30 \mathrm{~km}$ (direct) NNW of Badgingarra, Briggs 8587, Johnson, Meney, Pate \& Linder, 6 Sep 1990 (NSW, BOL, NBG, RSA).

Eurychorda B.G. Briggs \& L.A.S. Johnson, gen. nov.

Plantae caespitosae; vaginae culmorum appresae; antherae exsertae; chlorenchyma cellulis columnaris interruptum. A Chordifex distinguitur culmis valde compressis, testa e cellulis subangularibus planiusculis haud serialibus constata.

Type species: Eurychorda complanata (R. Br.) B.G. Briggs \& L.A.S. Johnson

Dioecious. Caespitose, the base pubescent in the axils of glabrous cataphylls. Culms simple, erect, striate, strongly compressed, edges of culms minutely scabrid, glabrous, with persistent appressed herbaceous sheaths with obtusely angled auriculate apices. Male and female inflorescences similar, with erect spikelets on slender peduncles, solitary or a few together at several upper nodes. Male spikelets: with 30-50 flowers and several sterile lower glumes. Female spikelets: flowers 5-13, with several sterile lower glumes; glumes aristate. Flowers: tepals 4, outer tepals keeled and sparsely pubescent. Male flowers: stamens 2, anthers exserted. Female flowers: ovary 2-locular, 


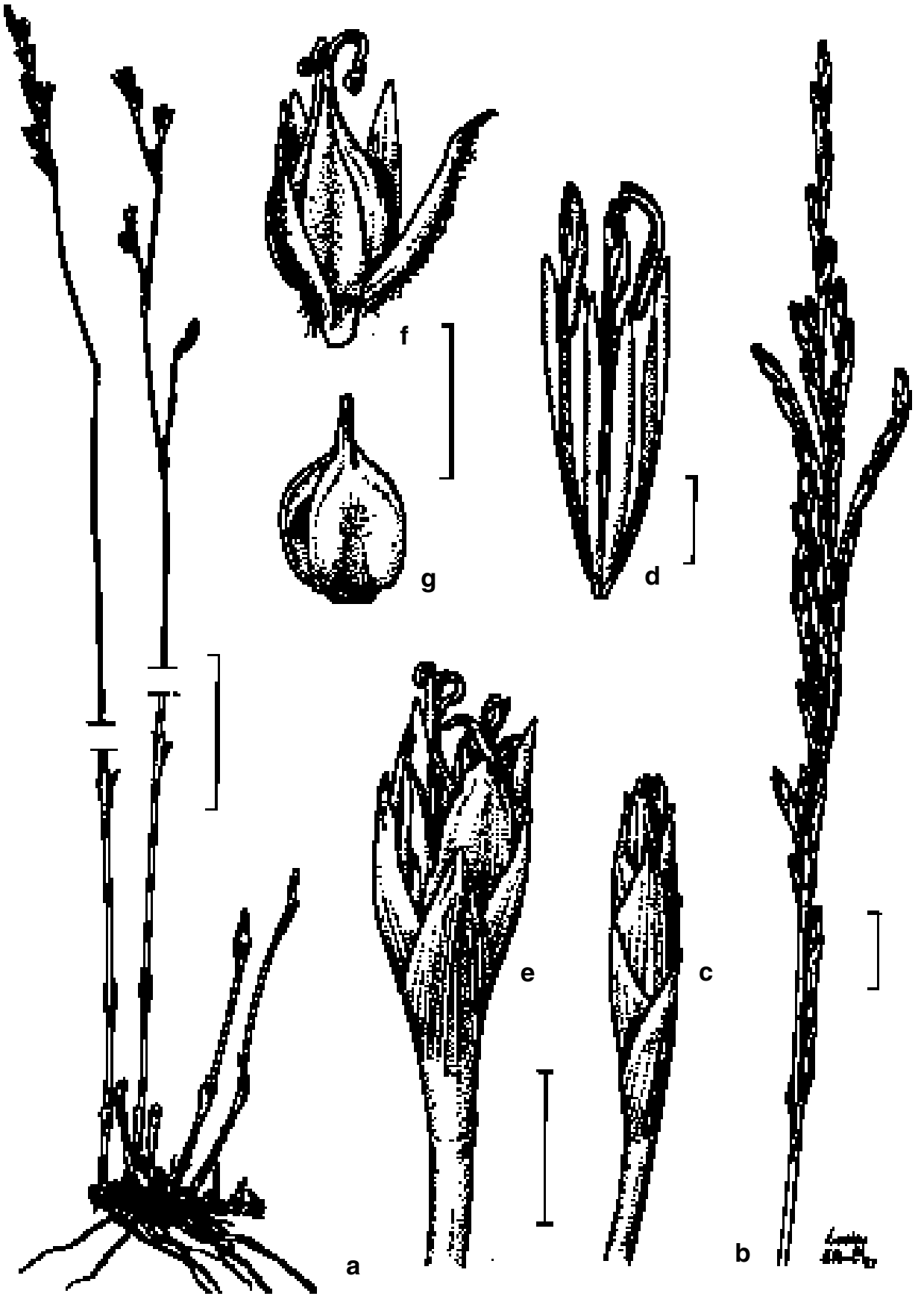

Fig. 4. Chordifex stenandrus. a, habit (holotype). b-d male: b, inflorescence. c, spikelet. d, flower, (Briggs 7475).e-h female: e, spikelet. f, fruit with perianth, (Briggs 7474). g, fruit (Briggs 8587). Scale bars: $\mathrm{a}=5 \mathrm{~cm} ; \mathrm{b}-\mathrm{c}, \mathrm{e}=4 \mathrm{~mm} ; \mathrm{d}, \mathrm{f}-\mathrm{g}=1 \mathrm{~mm}$. 
style branches 2 . Fruit a capsule. Seeds with irregular pattern of subangular or slightly lobed, flat or slightly convex, isodiametric cells. $2 n=24$ (Briggs 1963, as Restio complanatus) (Fig 5a-c).

Culm with chlorenchyma of 1-2 layers of short peg-cells, interrupted opposite some outer vascular bundles by pillar cells ( 1 or 2 together as seen in transverse section); girders and protective cells absent; central cavity present. Eurychorda shows a flavonoid pattern distinct from that of Chordifex and other allied genera (Williams et al. in press), including tricin and gossypetin as well as the more widely found luteolin.

The name is from the Greek eurys, broad or wide, and chorde, rope, referring to the broad, flattened culms.

Differences from related genera are given under Platychorda.

One species of eastern Australia from southern Queensland to Tasmania, in wet or seasonally wet sites.

Eurychorda complanata (R. Br.) B.G. Briggs \& L.A.S. Johnson, comb. nov.

Basionym: Restio complanatus R. Brown, Prodr.: 245 (1810).

Type citation: (J.) v.v.

Type: New South Wales: Port Jackson, R. Brown 1802-5 o (lecto, here selected, BM [mounted with some $q$ pieces]; isolecto E). Residual syntypes: Port Jackson, R. Brown 1802-5 + (BM); Derwent, R. Brown + (BM; isosyn E).

Platychorda B.G. Briggs \& L.A.S. Johnson, gen. nov.

A Chordifex combinatione characterum sequentium distinguitur: culmi compressi; antherae inclusae; loculi stylique 3; testa e cellulis subangularibus planiusculis haud serialibus constata; chlorenchyma costis sclerenchymatis interruptum, cellulis columnaribus nullis.

Type species: Platychorda applanata (Spreng.) B.G. Briggs \& L.A.S. Johnson

Dioecious. Caespitose, the base pubescent in the axils of glabrous cataphylls. Culms unbranched below the inflorescence, erect, striate, compressed, without scabrid edges, glabrous, with persistent appressed scarious or membranous sheaths with gradually tapering auriculate apices. Male and female inflorescences similar, spikelets at several or many nodes of slender branches, erect or the males somewhat pendulous; the branches singly or in clusters at several upper nodes. Spikelets with several flowers and many sterile lower glumes; glumes blunt or acute. Flowers: tepals 6, 2 outer tepals keeled. Male flowers: stamens 3, anthers not exserted. Female flowers: ovary 3-locular, style branches 3 . Fruit a capsule. Seeds with irregular pattern of subangular or slightly lobed, flat or slightly convex, isodiametric cells (Fig. $5 \mathrm{~d}-\mathrm{g}$ ).

Culm with chlorenchyma of 2-3 layers of short peg-cells; interrupted opposite outer vascular bundles by narrow, radially elongated sclerenchyma girders; pillars and protective cells absent; central cavity present. Platychorda shows a flavonoid pattern distinct from that of Chordifex and other allied genera (Williams et al. in press), including apigenin as well as the more widely found luteolin.

The name is from the Greek platys, broad, flat, and chorde, rope, referring to the broad and somewhat flattened culms.

Platychorda differs from Chordifex, Eurychorda, and Tremulina in retaining 3 loculi and 3 style branches. Tepal number is reduced to 4 in Eurychorda, but is 5 or 6 in the other genera. Seed surfaces show marked differences: Chordifex has striate seeds with lines of strongly convex cells, Tremulina has a distinctive regular pattern of flat rectangular 
cells (remarkably similar to that of Dielsia), while the other two genera have an irregular pattern of subangular flat or slightly convex cells. Chordifex and Eurychorda have pillar cells interrupting the chlorenchyma (generally opposite all outer vascular bundles in Chordifex but only some vascular bundles in Eurychorda), whereas pillars are lacking in Platychorda and Tremulina, in which the chlorenchyma is interrupted by sclerenchyma girders.

A genus of two species (one undescribed) of the south-west of Western Australia, in wet or seasonally wet sites.
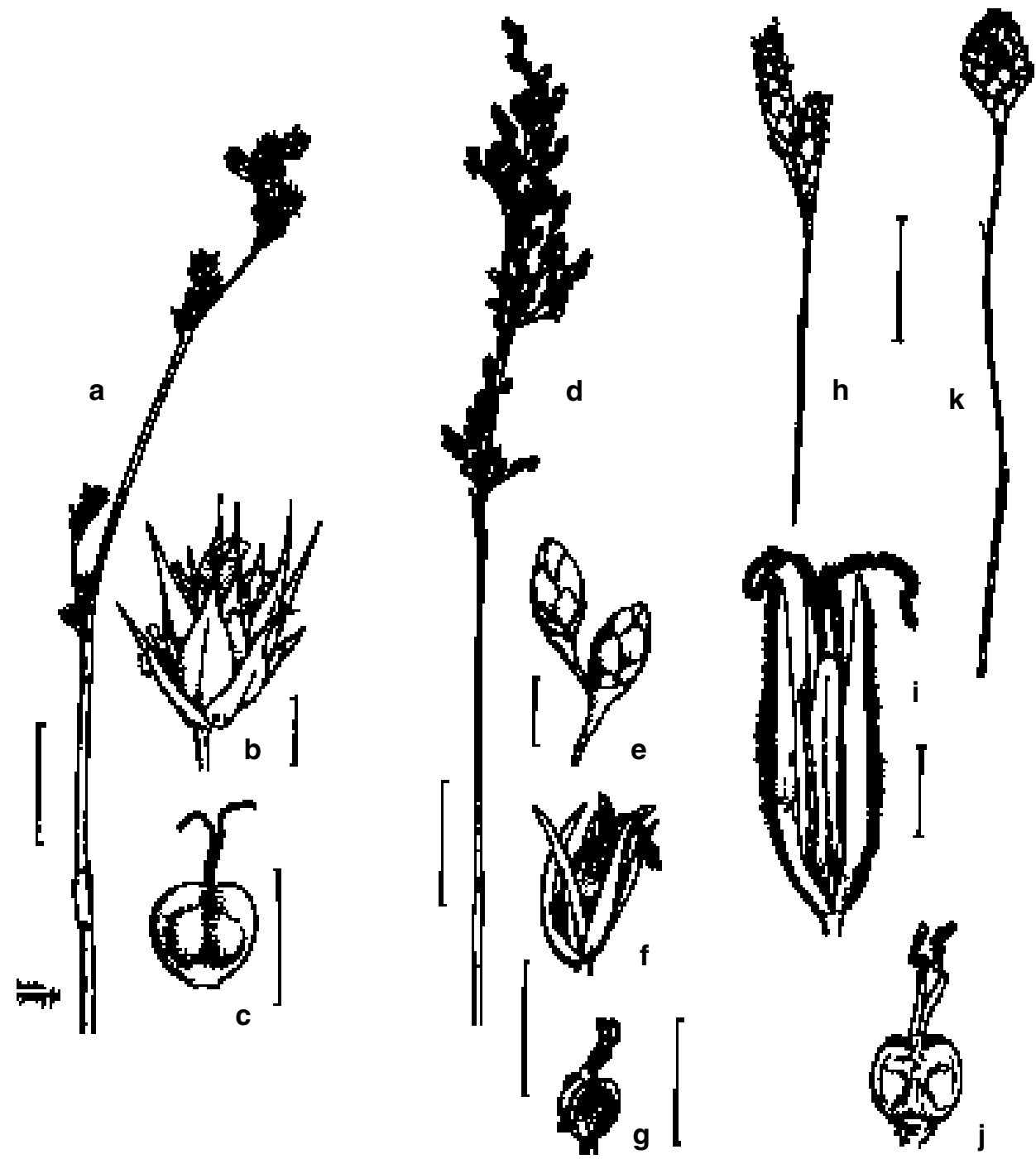

Fig. 5. a-c, Eurychorda complanata, female: a, inflorescence. b, spikelet. c, fruit (Lyne 357). d-g, Platychorda applanata, female: d, inflorescence. e, spikelets. f, young fruit. $\mathbf{g}$, old fruit (Briggs 8642). $\mathbf{h}-\mathbf{k}$, Melanostachya ustulata, $\mathbf{h}-\mathbf{j}$, female: $\mathbf{h}$, spikelets. $\mathbf{i}$, female flower. $\mathbf{j}$, fruit (Jackson, Jan 1913). k, male spikelet (Briggs 785). Scale bars: $a, d=2 \mathrm{~cm} ; b, c, e-g=2 \mathrm{~mm} ; \mathrm{h}, \mathrm{k}=1 \mathrm{~cm} ; \mathrm{i}, \mathrm{j}=1 \mathrm{~mm}$. 
Platychorda applanata (Spreng.) B.G. Briggs E L.A.S. Johnson, comb. nov.

Basionym: Restio applanatus Sprengel, Syst. Veg. 1: 185 (1825) = Restio compressus R. Brown, Prodr.: 245 (1810) nom. illeg., non Rottboell, Descr. icon. rar. pl. (1773).

Type citation: (M) v.v.

Type: Western Australia: KGS [King Georges Sound], R. Brown (Bennett 5863), 1802-5 o (lecto, here selected, BM). Residual syntype: KGS, R. Brown 1802-5 o (BM, 2 sheets).

Tremulina B.G. Briggs E L.A.S. Johnson, gen. nov.

A Chordifex combinatione characterum sequentium distinguitur: culmi plus minusve compressi; spiculae pedunculis tenuibus; tepala 6; antherae inclusae; testa e cellulis rectangularibus serialibus constata; chlorenchyma costis sclerenchymatis interruptum, cellulis columnaribus nullis.

\section{Type species: Tremulina tremula (R. Br.) B.G. Briggs \& L.A.S. Johnson}

Dioecious. Caespitose, the base pubescent but cataphylls glabrous. Culms unbranched or sometimes dimorphic with repeatedly branched sterile culms and taller less branched fertile culms, erect, strongly compressed or terete, without scabrid edges, striate, glabrous or the lowest internode pubescent with branched multicellular hairs; sheaths persistent, appressed, with blunt auriculate apices. Male and female spikelets terminal or at a few nodes on slender lateral branches borne singly or in clusters at several upper culm nodes; spikelets erect or the males pendulous. Male spikelets with 10-50 flowers; female spikelets with 1-8 flowers; both with several sterile lower glumes; glumes blunt or acute, not auriculate. Flowers: tepals 6, 2 outer tepals keeled. Male flowers: stamens 3, anthers not exserted. Female flowers: ovary 2-locular, stylebranches 2. Fruit a capsule. Seeds with longitudinal lines of flat, rectangular or rhombic cells which are transverse or oblique to the long axis.

Culm with chlorenchyma of 3-4 layers of short palisade cells, interrupted opposite some outer vascular bundles by sclerenchyma girders; pillars and protective cells absent; central cavity present. Tremulina shows a flavonoid pattern distinct from that of Chordifex and other allied genera (Williams et al. in press), including chrysoeriol as well as the more widely found luteolin.

The name is from the Latin tremulus, shaking, quivering, and -ina, a diminutive suffix, referring to the spikelets (especially on male plants) on long slender stalks and to the epithet of the type species.

Differences from related genera are given under Platychorda.

A genus of two species (one undescribed) of the south-west of Western Australia, in wet or seasonally wet sites.

Tremulina tremula (R. Br.) B.G. Briggs E L.A.S. Johnson, comb. nov.

Basionym: Restio tremulus R. Brown, Prodr.: 245 (1810).

Type citation: (M.) v.v.

Type: Western Australia: King George IIId Sd [Sound], R. Brown 1802-5 đo (lecto, here selected, BM, photo NSW; isolecto K). Residual syntype: King George IIId Sd [Sound], R. Brown 1802-5 ㅇ (BM, mounted on same sheet as holo).

Melanostachya B.G. Briggs E L.A.S. Johnson, gen. nov.

A Chordifex combinatione characterum sequentium distinguitur: spiculae magnae; carinae tepalorum exteriorum dense rufopubescentes; testa e cellulis planis elongatis 
parietibus sinuatis constata; chlorenchyma cellulis epidermalibus dilatatis interruptum, cellulis columnaribus nullis.

Type species: Melanostachya ustulata (F. Muell. ex Ewart \& Sharman) B.G. Briggs \& L.A.S. Johnson

Dioecious. Caespitose, the base pubescent. Culms terete, simple or occasionally with 1 or 2 branches, glabrous, striate, with persistent appressed sheaths. Male and female inflorescences similar, of large erect spikelets terminal or 2 or 3 at upper nodes, the spikelets with 10-20 flowers and several sterile glumes toward both base and apex; the glumes rigid, dark brown or black, obtuse or with a short rigid acute tip. Flowers: tepals 6, 2 outer tepals keeled and with dense red-brown hairs along the keel toward the apex, inner tepals flat. Male flowers: stamens 3, anthers exserted. Female flowers: ovary loculi and style-branches 2 . Fruit a capsule. Seeds broad-ellipsoid, with longitudinally elongated cells with sinuous walls (Fig. 5h-k).

Culm epidermis with greatly enlarged tanniniferous cells opposite outer vascular bundles; enlarged epidermal cells that extend to (and interrupt) the parenchyma sheath over sclerenchyma girders opposite the outer vascular bundles alternating with ones that extend only part-way through the chlorenchyma; chlorenchyma of 1 layer of elongated peg-cells, pillar and protective cells absent, central cavity present. Melanostachya shows a flavonoid pattern distinct from that of Chordifex and other allied genera (Williams et al. in press), including hypolaetin and flavone $\mathrm{C}$-glycosides, as well as the more widely found luteolin.

A genus of one species, of the south-west of Western Australia; in wet or seasonally wet sites.

Melanostachya ustulata (F. Muell. ex Ewart \& Sharman) B.G. Briggs \& L.A.S. Johnson, comb. nov.

Basionym: Restio ustulatus F. Muell. ex Ewart \& Sharman, Proc. Roy. Soc. Victoria 28: 237, t. XXVI, Figs 12-19 (1916).

Type (not cited in protologue [Ewart \& Sharman 1916]): Western Australia: [probably Geographe Bay distr.], Mrs Irvine, labelled 'The $q$ plant exhibited at Royal Society Nov. 1915' $q$ (lecto, here selected, MEL 14812 p.p., + piece on left of sheet). Residual syntypes: (MEL 14812 p.p.); Blackwood R., J. Forrest 'Exhibited at Royal Society Nov $1915^{\prime}$ ơ (MEL 14811, BM). Probable syntypes: Forrest ô (MEL 14813, 14815); Drummond 65 ơ (MEL 14814).

Cytogonidium B.G. Briggs \& L.A.S. Johnson, gen. nov.

A Chordifex combinatione characterum sequentium distinguitur: spiculae masculinae pendulae ramulis tenuibus; antherae inclusae; chlorenchyma cellulis epidermalibus valde dilatatis interruptum, cellulis columnaribus nullis.

Type species: Cytogonidium leptocarpoides (Benth.) B.G. Briggs \& L.A.S. Johnson

Dioecious or populations parthenocarpic and female only. Caespitose, the base pubescent. Culms terete, simple or sparsely branched, glabrous, striate, with persistent appressed sheaths. Male and female spikelets very different in appearance; solitary or several together at 1 or several upper nodes. Male spikelets pendulous on slender pedicels, with spreading lanceolate, acute glumes, 30-50 flowers and 1 or 2 sterile lower glumes. Female spikelets erect, ovoid, with broad ovate aristate glumes, 5-10 flowers and often 1-3 sterile lower glumes. Flowers: tepals 5, 2 outer tepals keeled and in females with dense red-brown hairs along the keel; inner tepals flat. Male flowers: stamens 3, anthers not exserted. Female flowers: ovary loculi and stylebranches 2 . Fruit a capsule. Seeds broad-ellipsoid, surface covered with convex cells 
in irregular longitudinal lines (not separated by lines of flat cells as in Chordifex).

Culm with chlorenchyma of 1 layer of elongated peg-cells, interrupted by greatly enlarged epidermal cells that extend outwards overarching the stomates and that mostly extend inwards to (and often interrupt) the parenchyma sheath over sclerenchyma girders opposite the outer vascular bundles, pillar and protective cells absent, central cavity present. Cytogonidium is similar in its flavonoids (including only hypolaetin) to Dielsia, Loxocarya cinerea and some Chordifex species (Williams et al. in press).

The name is from the Greek cyto,- relating to a cell, gonia, an angle or corner, and -idion, a diminutive suffix, referring to the lines of greatly enlarged cells that give the culms a striate appearance.

Cytogonidium is characterised by male spikelets pendulous on slender branches, anthers not exserted, and by the greatly enlarged epidermal cells that interrupt the chlorenchyma and parenchyma sheath and give a striate appearance to the culms.

A genus of one species of the south-west of Western Australia; in moist or seasonally moist sites.

Cytogonidium leptocarpoides (Benth.) B.G. Briggs \& L.A.S. Johnson, comb. nov.

Basionym: Restio leptocarpoides Bentham, Fl. Austral. 7: $229(1878)=$ R. deformis sensu Mueller, Fragm. 8: 65 (1873), non R. Br.

Types: Western Australia: Drummond 1st coll. 907 \& (lecto, here selected, MEL 14770; isolecto BM). Residual syntypes: Busselton, Pries + (MEL 14768, 14769); Swan River, Drummond 1st coll. 381 ơ (CGE, MEL 14763), 369 \% (MEL 14766, 14772, LUND). The lectotype is chosen from among specimens cited by Mueller, excluding Mueller's own collection from 'Circum montes Stirlingi' which Bentham regarded as possibly a separate variety of this species, and also excluding 'Drummond 869 ' since this appears to be a misreading of ' 369 '.

Taraxis B.G. Briggs \& L.A.S. Johnson, gen. nov.

A Chordifex et Tyrbastes combinatione characterum sequentium distinguitur: rhizomata glabrata; spiculae femineae uniflorae glumis tepalisque ad squamas reductis, ovariis uniloculatis; a Chordifex item distinguitur habitu serpenti et stylis plerumque 3.

Type species: Taraxis grossa B.G. Briggs \& L.A.S. Johnson

Dioecious. Rhizomatous, rhizome stout, glabrous except for tufts of hairs in the cataphyll axils. Culms stout near base, much branched, upper branches slender, flexuose, forming tangled masses, terete to compressed, striate, glabrous except in sheath axils, with appressed, persistent sheaths. Male spikelets in small clusters at several upper nodes. Female spikelets solitary at several upper nodes. Male spikelets 4-13-flowered, glumes mostly fertile. Female spikelets 1-flowered. Male flowers: tepals 5(or 6), 2 outer tepals keeled, inner tepals flat; stamens 3, anthers exserted. Female flowers: glumes and tepals reduced to very small membranous scales; ovary unilocular, laterally thickened on two edges, style branches (2)3, shortly connate. Fruit and seeds not known.

Chlorenchyma of 1 layer of elongated peg-cells interrupted by pillar cells over some outer vascular bundles, protective cells lacking; central cavity lobed or angular in the lower culm resulting from inner vascular bundles arranged in large aggregations that are separated by a broad band of sclerenchyma from the outer vascular bundles. Taraxis resembles Tyrbastes in having a basic luteolin/hypolaetin flavonoid profile but contains free luteolin and lacks tricin (Williams et al. in press). 
The name is from the Greek taraxis, a confusion, disturbance or trouble, referring to the habit, with tangled masses of culms, and to the confusion that has existed in the classification of this and allied taxa.

Resembling Tyrbastes in its trailing and repeatedly branching habit but differing in its long stout rhizomes, 1-flowered female spikelets, greatly reduced glumes and tepals, chlorenchyma (especially in the slender upper branches) interrupted by pillar cells; and in the distinctive grouping of culm vascular bundles, resulting in a lobed central cavity.

A genus of one previously undescribed species of the south-west of Western Australia, in a region of high rainfall.

Taraxis grossa B.G. Briggs E L.A.S. Johnson, sp. nov.

Culmi 0.5-2 m longi, implicati, 4-7mm diam. crassi versus bases; plantae plerumque cecidiophorae, gallis (10-)15-22 mm longis spiculis simulantibus.

Type: Western Australia: Carey Brook, Pemberton-Nannup Rd (E border of Manjimup Shire), W.A., 34² $25^{\prime} \mathrm{S} 115^{\circ} 49^{\prime} \mathrm{E}, 14$ Oct 1992, B.G. Briggs 9074 \& K. Meney ơ (holo NSW; iso $\mathrm{K}, \mathrm{MO}$, PERTH).

Rhizome stout, long creeping or ascending, 5-7 mm diam., with a tuft of hairs in scale axil. Culms stout, rigid, erect, forming large tangled masses to $2 \mathrm{~m}$ tall, yellowishgreen, 0.5-1.7 $\mathrm{m}$ long; 4-7 $\mathrm{mm}$ diam. at the base; tapering apically, flexuose, diam. decreasing to c. $0.5 \mathrm{~mm}$. Sheaths green to brown or straw-coloured; $1.5-3.0 \mathrm{~cm}$ long near the base; c. $0.5 \mathrm{~cm}$ long on the branches; lamina erect, terete, $1-3 \mathrm{~mm}$ long with pale membranous margins. Spikelets in the upper axils, males mostly in small clusters, females singly; subtending bracts: males c. 3-5 mm long, acute with a mucro to $4.0 \mathrm{~mm}$ long; females c. $8 \mathrm{~mm}$ long, $2 \mathrm{~mm}$ wide, acute. Male spikelets ellipsoidal, $3.3-7.0 \mathrm{~mm}$ long; glumes 4-13, acute to mucronate, keeled, 2.8-4.0 $\mathrm{mm}$ long, purplish to green to straw-coloured, mostly glabrous, or basally pubescent with long white hairs; mucro to $2.2 \mathrm{~mm}$ long. Female spikelets: 1-flowered, only the stigmas emerging from the subtending bract. Male flowers: tepals 5(6), lanceolate, acute; outer tepals slightly longer, 2.4-3.2 mm long; filaments 3-5 mm long; anthers 1.2-2.0 mm long. Female flowers: glumes apparently represented by 2 or 3 membranous, ovate scales c. $0.3 \mathrm{~mm}$ long; tepals deltoid c. $0.7 \mathrm{~mm}$ long; style branches fused 1/8-1/2 of length. Fruit and seeds rarely produced and not seen. Most plants bearing numerous large galls that resemble spikelets, $1.2-3.5 \mathrm{~cm}$ long with c. 80 sterile 'glumes', the 'glumes' 6-15 mm long, narrow elliptic, acuminate, green or straw-coloured (Fig. 6a-e, 7a).

Occurs in the south-west of Western Australia near Dwellingup and from the Busselton district to near Walpole, in a region of high rainfall, on seasonally or permanently wet sands and peats in swamps and along stream banks. Regenerates after fire or damage by resprouting.

Conservation status: Relatively common; not considered to be at risk (Meney, Pate \& Hickman in press), although some populations are remnants in areas subject to clearing and eutrophication.

Selected specimens examined: Western Australia: Darling: Dwellingup district, Stoate, Sep 1935 ơ (PERTH); Jindong, Busselton district, Royce, 4601 ơ 4602 †, 20 Oct 1953 (PERTH); Carbunup, Keighery \& Gibson 1008, 15 Oct 1992 ơ (PERTH, NSW); Carbunup River, 2 km S of Jindong, Briggs 8329b, 26 Oct 1988 ㅇ (NSW); Barlee Brook, 34 km SSE of Nannup, Briggs 7597 \& Johnson, 6 Oct 1984 o (NSW, AD, BRI, DNA, NBG, NY, PERTH, RSA); c. $5 \mathrm{~km}$ E of Karridale, $3.7 \mathrm{~km} \mathrm{~S}$ of Brockman Hwy on Glenarty Rd, Briggs 8366 \& Johnson, 27 Oct 1988 ô (NSW); Carey Brook, Pemberton-Nannup road, Briggs 9075 \& Meney, 14 Oct 1992 ㅇ (NSW); Brennans Ford, Scott R., Keighery 1871b, 3 Nov 1978 ơ (PERTH); Shannon River, c. 22 km E of Northcliffe, Pullen 9945, 10 
Dec 1974 ơ (CANB, BRI, NSW); $1.7 \mathrm{~km} \mathrm{~W}$ of Walpole, Briggs $7604 \mathcal{E}$ Johnson, 7 Oct 1984 ơ (NSW, $\mathrm{AD}, \mathrm{CANB}, \mathrm{K}, \mathrm{MEL}, \mathrm{MO}, \mathrm{PERTH})$; Walpole River, 1 mile [1.5 km] SW of Walpole, Briggs 653, 18 Sep 1966 ơ (NSW, CANB); near bridge on road to Pt. Nuyts, Wrigley, 14 Oct 1968 (CBG, NSW); Bow R., Jackson, Nov 1912 (NSW); 2 miles [3 km] S of Bow Bridge, on Peaceful Bay road, 12 miles [19 km] E of Walpole, Briggs 635, 17 Sep 1966 o (NSW, BRI, PERTH), 636 ơ (NSW, K).

Tyrbastes B.G. Briggs E L.A.S. Johnson, gen. nov.

A Taraxis combinatione characterum sequentium distinguitur: plantae caespitosae, basibus pubescentes; spiculae femineae floribus 1 usque ad pluribus, tepalis 6 , loculis 2 vel 3; chlorenchyma costis sclerenchymatis et cellulis epidermalibus dilatatis interruptum, sine cellulis columnaribus.

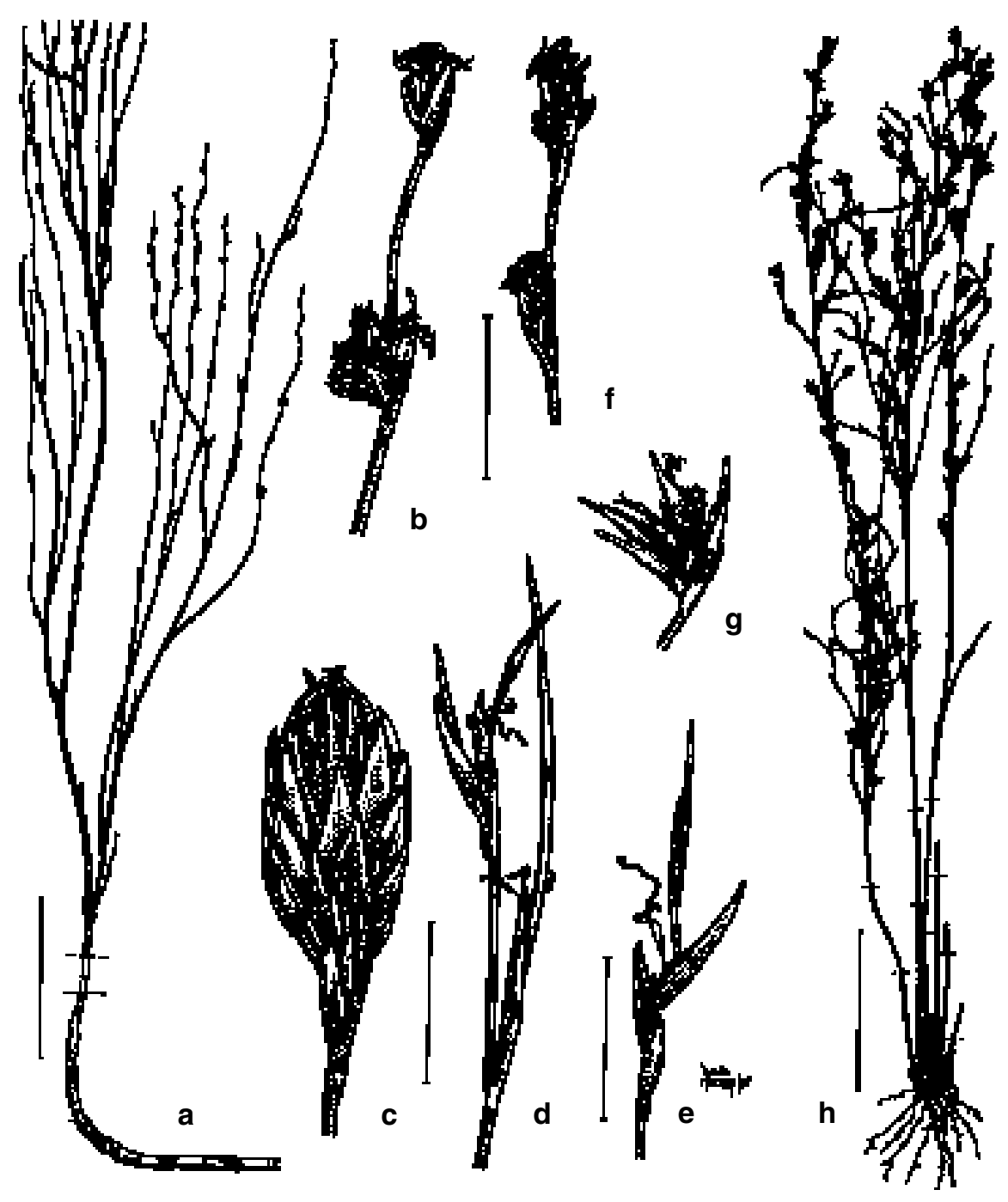

Fig. 6. a-e, Taraxis grossa, a-b, male: a, habit. b, spikelets (Briggs 9074). c-e, female: c, gall. d, e, spikelets (varying in number of style-branches) (Briggs 9075). $\mathbf{f}-\mathbf{h}$, Tyrbastes glaucescens, $\mathbf{f}$, male spikelets (Briggs 8337). g, h, female; g, spikelet (Briggs 9056). h, habit, (Briggs 8645). Scale bars: a, $\mathrm{h}=10 \mathrm{~cm} ; \mathrm{b}-\mathrm{g}=1 \mathrm{~cm}$. 
Type species: Tyrbastes glaucescens B.G. Briggs \& L.A.S. Johnson

Dioecious. Caespitose, the base pubescent. Culms slender, erect or trailing, flexuose and much-branched, often forming tangled masses, terete to compressed, striate, glabrous except in sheath axils, with appressed, persistent sheaths. Inflorescences of spikelets mostly singly at the upper nodes. Male spikelets of several or many flowers. Female spikelets with 1-several flowers. Male flowers: tepals 6, 2 outer tepals keeled, inner tepals flat; stamens 3, anthers exserted. Female flowers: tepals 6, outer tepals longer than inner; ovary loculi and style-branches 2(3), branches shortly connate. Fruit a thin-walled capsule. Seed ellipsoid, with distinctive pattern of slightly convex, slightly lobed cells in indistinct rows.

Culms with enlarged epidermal cells interrupting the chlorenchyma and meeting the parenchyma sheath over low girders opposite some outer vascular bundles; chlorenchyma of 2-3 layers of short peg-cells; pillars and protective cells lacking; central cavity present (not lobed). In flavonoid constituents Tyrbastes is similar to the morphologically very different Alexgeorgea; it also resembles Taraxis in having a basic luteolin/hypolaetin flavonoid profile but contains tricin and lacks free luteolin (Williams et al. in press).

The name is from the Latin tyrbastes, a trouble-maker or agitator, referring to the difficulty we have had in determining the affinities of the genus.

Similar in general appearance to Taraxis but differing in the caespitose habit, pubescent base, female spikelets usually of several flowers (but the axis extended so that the glumes do not form a compact spikelet), well developed tepals, ovary 2- or 3-locular, chlorenchyma interrupted by sclerenchyma ribs and enlarged epidermal cells but without pillar cells; also generally lacking the galls that are such a prominent feature of Taraxis.

A genus of one species of the south-west of Western Australia, in a region of high rainfall.

Tyrbastes glaucescens B.G. Briggs E L.A.S. Johnson, sp. nov.

Culmi erecti, ramosissimi, implicati, 0.3-1 m longi, 1.0-1.5 mm diam. versus bases; spiculae masculinae $4-7.5 \mathrm{~mm}$ longae; flores feminei tepalis 3-4 mm longis.

Type: Western Australia: Brockman Highway, c. $11 \mathrm{~km}$ E of Alexandra Bridge, $8.6 \mathrm{~km}$

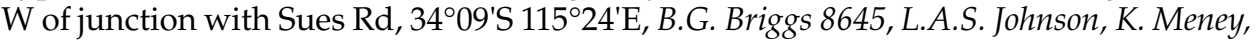
J. Pate \& P. Linder, 10 Sep 1990 \& (holo NSW; iso CANB, K, MEL, PERTH).

Plant tufted; with scales covering a pale woolly pubescence. Culms erect or spreading, flexuose, minutely dotted with tanniniferous cells, dull-grey to green or yellowish, 0.3-1.0 m long; $1.0-1.5 \mathrm{~mm}$ diam. basally, upper branches $0.5-1 \mathrm{~mm}$ diam. Sheaths $0.5-2.0 \mathrm{~cm}$ long, green to light-brown or often speckled; mucro narrow, compressed to terete, to $2-3 \mathrm{~mm}$ long, occasionally longer; margin narrow, caducous, membranous. Spikelets sessile or on short pedicels at upper nodes; subtending bracts green to lightbrown, with a reddish tinge when young, 2.5-4.5 mm long; mucro erect, terete, to $3 \mathrm{~mm}$ long. Male spikelets narrow-ovoid, 4.0-7.5 mm long; glumes 4-10(-24), mostly fertile, mucronate, green to golden-brown with a reddish apex, glabrous, 1.7-2.5 mm long; mucro, short, blunt, c. 0.5-1.4 mm long. Female spikelets when 1-flowered usually with 1-several abortive flowers below or above the fertile flower, often with an elongated axis so that the glumes do not overlap; glumes mostly subtending a flower or abortive flower, narrow-ovate, acute to subulate, herbaceous, green or pale-brown, glabrous, 5.0-6.0 $\mathrm{mm}$ long, mucro to $2.2 \mathrm{~mm}$ long, the axis with 2 membranous narrow-linear glumes $4 \mathrm{~mm}$ long. Male flowers: outer tepals narrow-lanceolate, 1.8-3.2 mm long; inner tepals \pm lanceolate, c. $2.0-2.5 \mathrm{~mm}$ long; filaments $2.5-3.5 \mathrm{~mm}$ long, to c. $0.3 \mathrm{~mm}$ wide; anthers $1.2-1.6 \mathrm{~mm}$ long. Female flowers: outer tepals c. $4 \mathrm{~mm}$ 
long, narrow-linear, hyaline; inner tepals narrow oblong, hyaline, acute, 3-4 mm long; staminodes sometimes present, c. $0.5 \mathrm{~mm}$ long. Capsule $2.0-2.5 \mathrm{~mm}$ long, dark brown. Seed 1.0-1.3 mm long (Fig. $6 \mathrm{f}-\mathrm{h}, 7 \mathrm{~b}, \mathrm{c}$ ).

Occurs in the south-west of Western Australia near Collie and from the Busselton district to Albany, in a region of high rainfall, on seasonally or permanently wet sands and peats in swamps and along stream banks. Regenerates by seed after fire.

Conservation status: Relatively widespread and common although some populations are remnants in areas subject to clearing and eutrophication.

Selected specimens examined: Western Australia: Darling: Harris River, $3 \mathrm{~km} \mathrm{~S}$ of Collie, Briggs 6707, 10 Oct 1976 9 (NSW, PERTH), 6709 ơ (NSW, AD, PERTH); Carbunup River, 1.5 miles [2 km] SW of Jindong, Busselton district, Briggs 873a, 20 Sep 1966 ơ (NSW, CANB, K, MO, NY, PERTH); The Rapids, Margaret R., Briggs 8337 \& Johnson, 26 Oct 1988 ơ (NSW), 8338, ㅇ (NSW, B, L, PERTH); Black Point Rd, 9 km SW of Fouracres Rd, Gibson \& Lyons 113, 5 Apr 1991 ๆ (PERTH); Brennans Ford (Scott River crossing), ENE of Augusta, Strid 21414, 16 Nov 1982 o (PERTH, NSW); Gingilup Swamps Nature Reserve, Gibson \& Lyons 567, 18 Apr 1991 ㅇ (PERTH); Walpole River, 1 mile [1.5 km] SW of Walpole on west bank, Briggs 655, 18 Sep 1966 o (NSW, K, MO, MEL, NBG, NY, PERTH); Bow R., Jackson, Jan 1913 \& (NSW); W side of Bow River at Bow Bridge, Briggs 6543, 3 Oct 1976 ô (NSW, CANB, MEL, PERTH); west shore of King Georges Sound, c. 5 miles [9 km] from Albany, K. Mair E26, Oct 1965 ơ (NSW).

Leptocarpus group (Briggs \& Johnson in press)

All species of this group were formerly included in the genera Leptocarpus and Hypolaena. DNA sequence data (Briggs, Marchant, Gilmore \& Porter unpublished

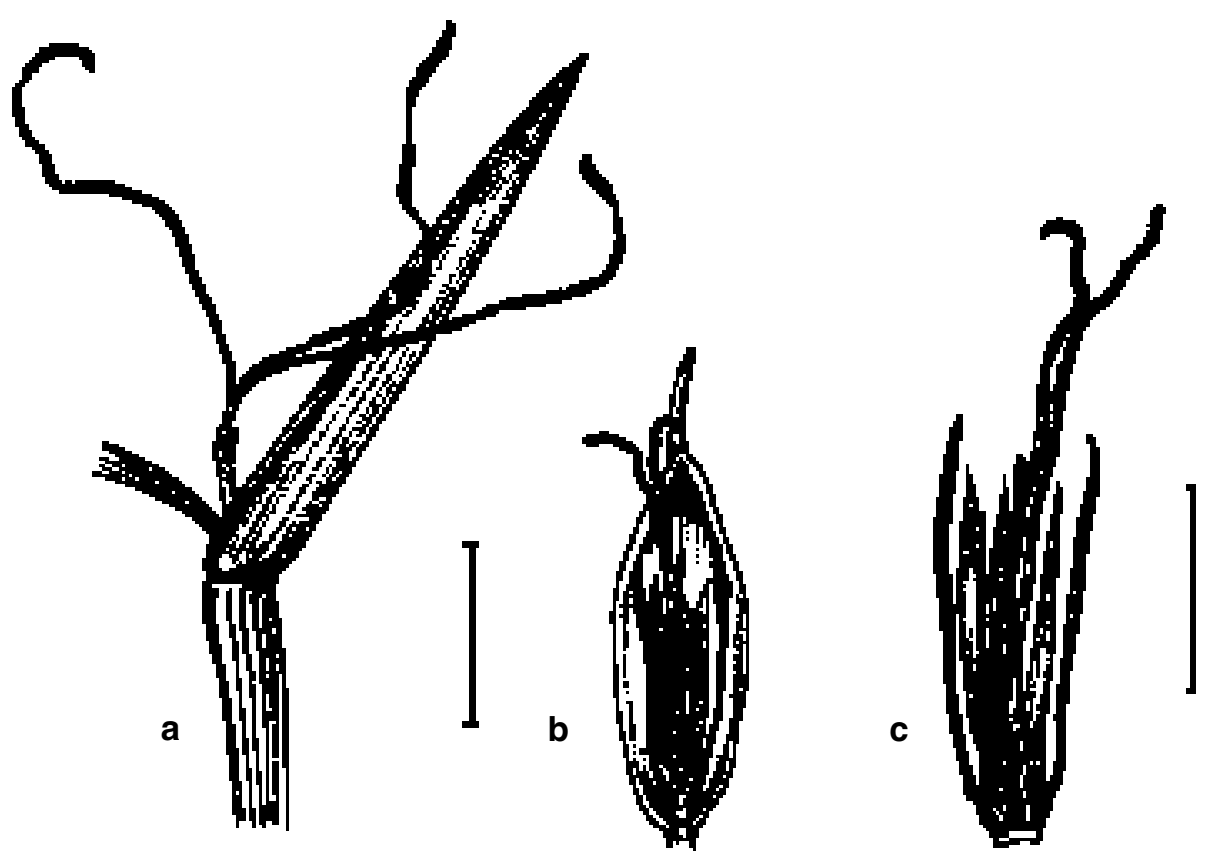

Fig. 7. Taraxis and Tyrbastes, female spikelets and subtending bracts. a, Taraxis grossa, female flower (1-flowered spikelet) in axil of subtending bract, tepals represented by small scales (Briggs 9075). b, c, Tyrbastes glaucescens, female flower (and glume), adaxial and abaxial (Briggs 8645). Scale bars: $\mathrm{a}, \mathrm{b}=3 \mathrm{~mm}, \mathrm{c}=2 \mathrm{~mm}$. 
results) show the members sampled forming a robust association. Examination of inflorescence structure has shown that what have been described as spikelets are diverse and not equivalent in the different taxa. Our observations and interpretations accord with those of Kircher (1986) for taxa that he studied. The spikelet may be simple (Leptocarpus) or compound (other genera). The dispersal unit is a compound spikelet (Hypolaena p.p.), or is an individual spikelet (flower with stalk and one or two bracts on the axis (Hypolaena p.p., Leptocarpus, Meeboldina, Stenotalis, Dapsilanthus and Apodasmia) or consists of the flower and glume only (Chaetanthus). The fruit is a nut with a pericarp that is hard and woody (Hypolaena) or thin and papery (other genera).

Note: The application of the name Leptocarpus used here will require conservation of a new type for the genus. This will be sought to avoid nomenclatural change to its most widespread member and to Chaetanthus.

\section{Key to genera of Leptocarpus group}

1 Pericarp of nut woody Hypolaena

$1^{*}$ Pericarp of nut thin-textured 2

2 Female flowers in distinct spikelets, spikelets not compound, with no bracts between the flower and subtending glume; flowers dorsiventrally flattened with winged lateral tepals Leptocarpus

2* Female flowers in large clusters without conspicuous spikelet structure or in compound spikelets with small bracts between the flower and subtending glume; flowers not dorsiventrally flattened (sometimes laterally flattened) 3

3 Male flowers with a globular swollen base; females with clusters of 3-5 flowers crowded into larger aggregations; culms simple below the inflorescence 4

$3^{*}$ Male flowers without a swollen base, female spikelets distinct or females crowded into large aggregations; culms simple or branched

4 Caespitose, fruiting perianth with awns or slender tepals 2-8 times as long as fruit Chaetanthus

$4^{*}$ Rhizomatous, fruiting perianth with ovate or lanceolate tepals less than 2 times as long as fruit Apodasmia

5 Female flowers in clusters of 3-5 which are crowded into larger aggregations (without conspicuous spikelet structure); male inflorescences appearing similar to the females and with exserted anthers or of distinct pendulous spikelets with non-exserted anthers Dapsilanthus

$5^{*}$ Female flowers in distinct spikelets (compound spikelets); male and female inflorescences very different in appearance; male spikelets pendulous and anthers not exserted

6 Female spikelets (compound spikelets) very slender, 1- or 2-flowered; culms much branched Stenotalis

$6^{*}$ Female spikelets (compound spikelets) not very slender, several or many-flowered; culms branched or simple Meeboldina

Stenotalis B.G. Briggs \& L.A.S. Johnson, gen. nov.

A Leptocarpus combinatione characterum sequentium distinguitur: culmi ramosissimi; inflorescentiae masculinae femineaeque spiculis in fasciculis parvis dispositis, in 
ramulis dispersis; spiculae femineae compositae floribus 1 vel 2, pedicellis unibracteatis, floribus non dorsiventraliter compressis, pari extimo tepalorum non alato.

Type species: Stenotalis ramosissima (Gilg) B.G. Briggs \& L.A.S. Johnson

Dioecious. Caespitose with ascending rhizomes, base pubescent. Culms much branched, striate, with appressed 'fan-hairs'; with persistent appressed sheaths. Inflorescence: males and females very different, male spikelets usually numerous, several to many-flowered, pendulous; female flowers in very narrow 'spikelets' with 1 or 2 flowers but which are compound with 1 bract on the flower-stalk. Male flowers: tepals 5, stamens (2)3, not exserted. Female flowers: tepals 6, ovary 1-locular, style branches 3 . Fruit a small, thin-walled nut, shed with enclosing glume and persistent perianth. Seed ellipsoid, smooth.

Culm with chlorenchyma of 2-4 layers of short cells arranged in transverse plates, interrupted by pillar cells opposite the outer vascular bundles. The flavonoids of Stenotalis are those common to most members of the Leptocarpus group of genera: luteolin, hypolaetin, flavonoid sulphates and flavone glucuronides, but also with quercetin reported in one sample (Williams et al. in press).

The name is from the Greek stenos, narrow, and talis, a marriageable maiden, referring to the very slender female spikelets.

Stenotalis is characterised by much-branched culms, slender female inflorescences of 1 or 2 flowers in compound spikelets, bearing a bract on the flower stalk.

A genus of one species in the south of Western Australia, in seasonally moist sites.

Stenotalis ramosissima (Gilg) B.G. Briggs \& L.A.S. Johnson, comb. nov.

Basionym: Hypolaena ramosissima Gilg, Bot. Jahrb. Syst. 35: 89 (1904).

Type: Western Australia: pr. King George Sound ad lacum Grasmere, Diels 5500 p.p., Nov. [1901] $q$ (lecto, here selected, B). Residual syntype: Diels 5500 p.p. ô (isosyn K).

Dapsilanthus B.G. Briggs \& L.A.S. Johnson, gen. nov.

A Leptocarpus combinatione characterum sequentium distinguitur: culmi ramosissimi; inflorescentia feminea e spiculis 3-5 floribus constata, sed spiculae confertae, pedicellis unibracteatis, floribus non dorsiventraliter compressibus, tepalis pari extimo non alatis.

Type species: Dapsilanthus elatior (R. Br) B.G. Briggs \& L.A.S. Johnson

Dioecious. Caespitose or rhizomatous, base pubescent. Culms branched, striate, with appressed or spreading 'fan-hairs' and persistent appressed sheaths. Male and female inflorescences similar or dissimilar, branched. Male spikelets distinct and pendulous with non-exserted anthers or small, erect, in dense clusters and with exserted anthers. Female inflorescences compound, with clusters (true spikelets) of 3-5 very small flowers each with 1 bract on the 'flower-stalk' crowded in larger aggregations. Flowers: tepals hyaline or scarious, acute or acuminate; outer tepals keeled. Male flowers with 4-6 tepals and 2-3 stamens, anthers mostly exserted. Female flowers: tepals 6; ovary 1-locular; style-branches 3 . Fruit a small, thin-walled nut, shed with enclosing glume, bract and persistent perianth. Seed smooth, with a pattern of subangular cells (Fig. 8a-8e).

Culm with chlorenchyma of 2-4 layers of short cells arranged in transverse plates, interrupted by pillar cells opposite the outer vascular bundles; usually with an inner sclerenchyma sheath 1 cell layer thick separating the outer and inner ground tissue. Dapsilanthus shows a hypolaetin plus luteolin flavonoid pattern that is more similar to 
Hypolaena than to other members of the Leptocarpus group of genera (Williams et al. in press).

The name is from the Greek dapsilis, abundant or plentiful, and anthos, flower, referring to the very numerous flowers in the inflorescence.

Four species; three in seasonally wet sites in northern Australia and monsoonal areas of southern New Guinea (two of these also in the Aru Islands), as well as one species in south-east Asia (Malaysia, Cambodia, Thailand and the southeastern Chinese island of Hainan).

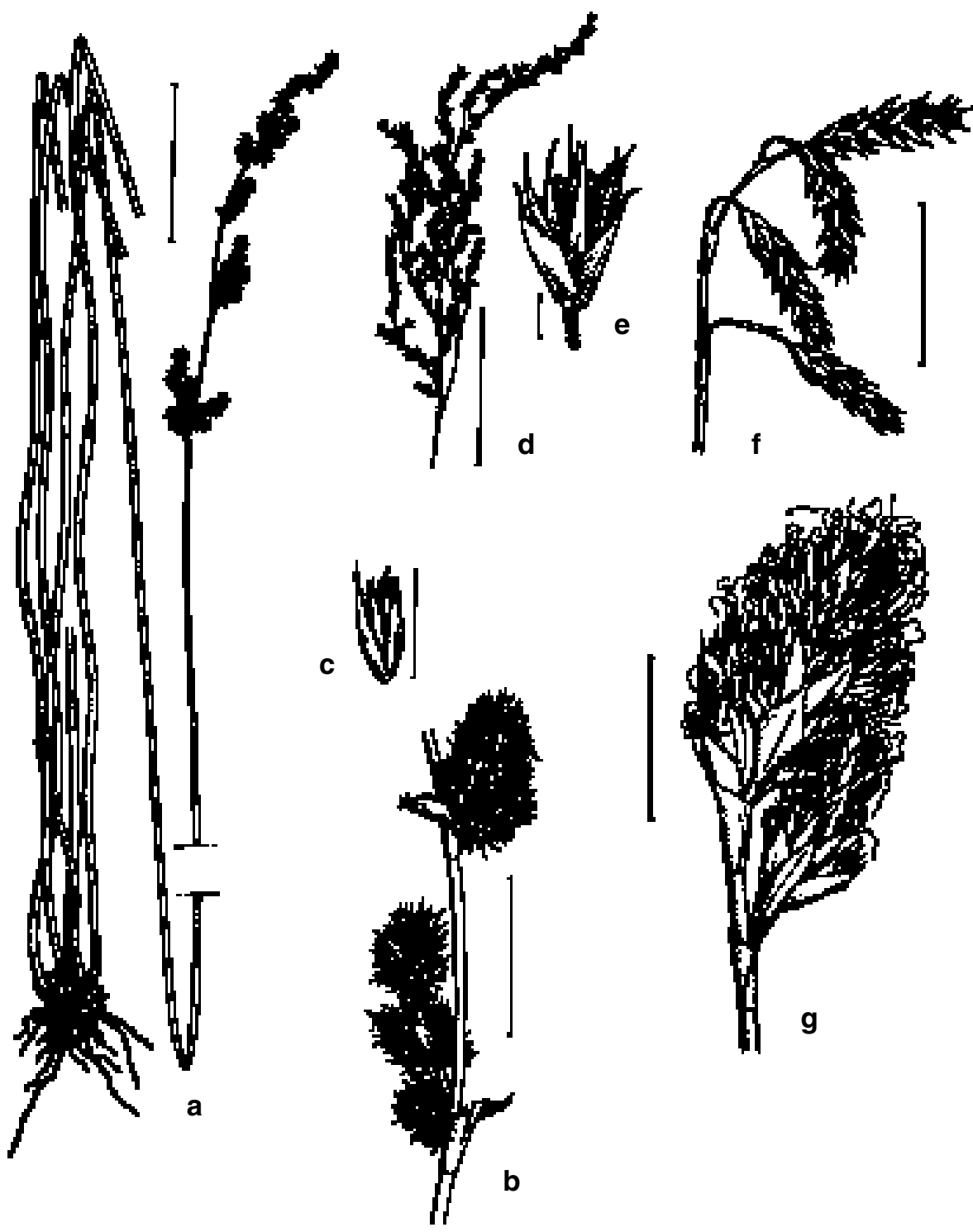

Fig. 8. a-e, Dapsilanthus elatior, $\mathbf{a}-\mathbf{c}$, female: $\mathbf{a}$, habit. $\mathbf{b}$, inflorescence. $\mathbf{c}$, capsule with tepals and glume (disseminule) (Clarkson 4995). d, e, male: d, inflorescence, e, spikelet (Cowie 3222). f, g, Apodasmia brownii, f, male spikelets (Beauglehole 19995b); $\mathbf{g}$, female, part of inflorescence (Briggs 2922). Scale bars: $a, d=5 \mathrm{~cm} ; b=1 \mathrm{~cm} ; c, e=1 \mathrm{~mm} ; f=7 \mathrm{~mm} ; g=14 \mathrm{~mm}$. 
Dapsilanthus elatior (R. Br.) B.G. Briggs E L.A.S. Johnson, comb. nov.

Basionym: Leptocarpus elatior R. Brown, Prodr.: 250 (1810).

Type citation: (T.) v.v.

Type: G. [Gulf] of Carpentaria, R. Brown (Bennett No. 5875), ㅇ (holo BM; iso BRI, E, K).

Apodasmia B.G. Briggs E L.A.S. Johnson, gen. nov.

A Leptocarpus combinatione characterum sequentium distinguitur: culmi infra inflorescentias simplices; flores masculini basi globosi tumidi; spiculae femineae compositae floribus 3-5 sed spiculae confertae, pedicellis unibracteatis, floribus non dorsaliventraliter compressis, pari extimo tepalorum non alato.

Type species: Apodasmia brownii (Hook. f.) B.G. Briggs \& L.A.S. Johnson

Dioecious. Rhizomatous, base pubescent. Culms unbranched below the inflorescence, striate, glabrous to densely pubescent; with appressed, or spreading 'fan-hairs' and persistent appressed sheaths. Male and female inflorescences similar or dissimilar, branched, spikelet structure obvious in males or obscured by clustering in both males and females. Male spikelets erect or pendulous, with partly exserted anthers. Female inflorescences compound, with clusters (true spikelets) of 3-5 very small flowers each with 1 bract on the 'flower-stalk' crowded in larger aggregations. Flowers: tepals hyaline or scarious, acute or acuminate; outer tepals keeled. Male flowers: the base globular and swollen; tepals 4-6; stamens 3, anthers mostly exserted. Female flowers: tepals 5-6, rigid; ovary 1-locular; styles 3, fused at base. Fruit a small, thin-walled nut, shed with enclosing glume, bract and persistent perianth. Seed smooth, with a pattern of subangular cells (Fig. 8f-8g).

Culm with chlorenchyma of 2-4 layers of short cells arranged in transverse plates, interrupted by pillar cells opposite the outer vascular bundles and usually with an inner sclerenchyma sheath of 1 cell layer separating the outer and inner ground tissue. Apodasmia shows a very homogeneous and unusual flavonoid profile with gossypetin 7-methyl ether (found elsewhere in Australian Restionaceae only in the very dissimilar Catacolea) as a major constituent (Williams et al. in press). The species from South Australia and Chile have identical aglycone flavonoid patterns with the same unusual glycoside (3-galactoside-8-glucoside) while the Western Australian species contain several additional flavonoids.

The name is from the Greek apodasmios, separated, referring to the widely disjunct distribution of the species.

A genus of four species, one each in the south of Western Australia (undescribed), south-eastern Australia, New Zealand, and Chile.

Apodasmia brownii (Hook. f.) B.G. Briggs \& L.A.S. Johnson, comb. nov.

Basionym: Leptocarpus brownii J.D. Hooker, Fl. Tasman. 2: 73, t.136 (1858).

Type citation: Gunn 338, masc; 778, 964 in Herb Lindl., et 1444, foem.

Type: Circular Head, Gunn 338, 15.9.[18]38 o (lecto, here selected, K). Residual syntypes: Banks of Derwent Gunn 338, 31.12.[18]40 (K); V.D. [Van Diemens] Land, Gunn 338 ô (herb Lindley CGE); Tasmania, R.C. Gunn ex herb Hooker ô (CGE). Probable isolecto or isosyn: Gunn s.n. ơ (GH, K, US), 오 (B). 


\section{Acknowledgments}

Many people assisted in this study over the years. Thanks are due especially to Carolyn Porter, Siegfried Krauss, Anna-Louise Quirico, Vivian Shanker, Barbara Wiecek, Louisa Murray, Kate Green and the late Ann Williams. David Mackay, Lesley Elkan and Nicola Oram used their expertise in producing the illustrations. Peter Wilson kindly assisted with the Latin diagnoses and nomenclature. The opportunity to examine specimens on loan or in other herbaria assisted the work. Cooperation and joint fieldwork with John Pate (University of Western Australia), and Kathy Meney and Kingsley Dixon (Kings Park and Botanic Garden, Perth) gave valuable insights, as did associated DNA sequencing studies with Adam Marchant, Simon Gilmore and Carolyn Porter and investigations of flavonoids by Christine Williams and Jeffrey Harborne (University of Reading). Unpublished data were kindly made available by Peter Linder (University of Cape Town, South Africa). Grants from the Australian Research Council, Australian Biological Resources Study and the Australia and Pacific Science Foundation provided valuable technical help and supported field studies.

\section{References}

Bentham, G. (1878) Flora Australiensis, vol. 7.

Briggs, B.G. (1963) Chromosome numbers in Lepyrodia and Restio in Australia. Contr. New South Wales Natl Herb. 3: 228-232.

Briggs, B.G. \& Johnson, L.A.S. (in press) A guide to a new classification of Restionaceae and allied families. In Meney, K.A. \& Pate, J.S. (eds), Australian Rushes - Biology, Identification and Conservation of Restionaceae and Allied Families. (University of Western Australia Press: Perth).

Briggs, J. \& Leigh, J. (1996) Rare or Threatened Australian Plants. Australian National Parks \& Wildlife Service, Special Publication no. 14.

Brown, R. (1810) Prodromus Florae Novae Hollandiae et Insulae Van Diemen.

Chanda, S. (1966) On the pollen morphology of the Centrolepidaceae, Restionaceae and Flagellariaceae, with special reference to taxonomy. Grana Palynologica 6: 355-415.

Cutler, D.F. (1969) Juncales. In Metcalfe, C.R. (ed.) Anatomy of Monocotyledons. Vol. 4. (Clarendon Press: Oxford)

Cutler, D.F. (1972) Vicarious species of Restionaceae in Africa, Australia and South America. Pp. 73-83 in D.H. Valentine (ed.), Taxonomy, Phytogeography and Evolution. (Academic Press: London).

Ewart, A.J. \& Sharman, P.J. (1916) Contributions to the flora of Australia, No. 24. Proc. Roy. Soc. Victoria 28: 230-239.

Gilg, E. (1890) Beiträge zur vergleichenden Anatomie der xerophilen Familie der Restionaceae. Bot Jahrb. Syst. 13: 541-606.

Harborne, J.B. (1979) Correlations between flavonoid chemistry, anatomy and geography in the Restionaceae. Phytochemistry 18: 1323-1327.

Johnson L.A.S. \& Briggs, B.G. (1981) Three old southern families - Myrtaceae, Proteaceae and Restionaceae. Pp. 427-464 in A. Keast (ed.), Ecological Biogeography of Australia. (W. Junk: Hague).

Kircher, P. (1986) Untersuchungen zur Blüten- und Infloreszenzmorphologie, Embryologie und Systematik der Restionaceen im Vergleich mit Gramineen und verwandte Familien. Diss. Bot. 94.

Linder, H.P. (1984) A phylogenetic classification of the genera of the African Restionaceae. Bothalia 15: 11-76.

Linder, H.P. (1992) The gynoecia of Australian Restionaceae: morphology, anatomy and systematic implications. Austral. Syst. Bot. 5: 227-245.

Linder, H.P., Briggs, B.G. \& Johnson, L.A.S. (in press) Restionaceae. In K. Kubitzki (ed.), The Families and Genera of Flowering Plants. (Springer-Verlag: Berlin).

Linder, H.P. \& Ferguson, I.K. (1985) On the pollen morphology and phylogeny of the Restionales and Poales. Grana 24: 65-76.

Meney, K.A., Dixon, K.W. \& Pate, J.S. (1997) Reproductive potential of obligate seeder and resprouter herbaceous perennial monocots (Restionaceae, Anarthriaceae, Ecdeiocoleaceae) from south-western Western Australia. Austral. J. Bot. 45: 771-782. 
Meney, K. A. \& Pate, J. S. (eds) (in press) Australian Rushes - Biology, Identification and Conservation of Restionaceae and Allied Families. (University of Western Australia Press: Perth).

Meney, K.A., Pate, J.S. \& Dixon, K.W. (1996) New species of Restionaceae from Western Australia. Telopea 6: 649-666.

Meney, K.A., Pate, J.S., Dixon, K.W., Briggs, B.G. \& Johnson, L.A.S. (in press) Conservation of Australian Restionaceae. In K.A. Meney \& J.S. Pate (eds), Australian Rushes - Biology, Identification and Conservation of Restionaceae and Allied Families. (University of Western Australia Press: Perth).

Meney, K.A., Pate, J.S. \& Hickman, E.J. (in press) Morphological and anatomical descriptions of Restionaceae, Anarthriaceae, and Ecdeiocoleaceae. In K.A. Meney \& J.S. Pate (eds), Australian Rushes - Biology, Identification and Conservation of Restionaceae and Allied Families. (University of Western Australia Press: Perth).

Mueller, F. (1872-1874) Fragmenta Phytographix Australix, vol. 8 (Government Printer: Melbourne).

Pate, J.S. \& Delfs, J.C. (in press) Anatomical features of Restionaceae and allied families. In K.A. Meney \& J.S. Pate (eds) Australian Rushes - Biology, Identification and Conservation of Restionaceae and Allied Families. (University of Western Australia Press: Perth).

Pate, J.S., Meney, K.A. , Dixon, K.W. (1991) Contrasting growth and morphological characteristics of fire-sensitive (obligate seeder) and fire-resistant (resprouter) species of Restionaceae (S. Hemisphere restiads) from south-western Australia. Austral. J. Bot. 39: 505-525.

Pate, J.S., Rasins, E., Thumfort, P.P., McCheseney, C.J. \& Meney, K.A. (1995) Occurrence of the unusual amino compound $S$-methyl cysteine in Australian members of the Restionaceae: biological and taxonomic significance. Austral. J. Bot. 43: 441-451.

Rye, B.L. (1987) Restionaceae (Family 151). Pp. 908-923 in N.G. Marchant, J.R. Wheeler, B.L. Rye, E.M. Bennett, N.S. Lander \& T.D. Macfarlane, Flora of the Perth Region, part two. (Western Australian Herbarium: Perth)

Williams, C.A., Harborne, J.B., Greenham, J., Briggs, B.G. \& Johnson, L.A.S. (1997) Flavonoid evidence and the classification of the Anarthriaceae within the Poales. Phytochemistry 45: 1189-1196.

Williams, C.A., Harborne, J.B., Greenham, J., Briggs, B.G. \& Johnson, L.A.S. (in press) Flavonoid patterns and the revised classification of Australian Restionaceae. Phytochemistry. 
